\title{
Los cristianos y la violencia (1968) $)^{*}$
}

\author{
Ignacio Martín-Baró
}

\begin{abstract}
Ce qui ne va pas, c'est que l'Eglise parfois proclame l'Evangile en paroles, alors qu'elle devrait le proclamer en actes.
\end{abstract}

Dr. Carson Blake

\section{Introducción}

A 1968 se le ha calificado periodísticamente como el año de la violencia. Numerosos acontecimientos, cuyo último sentido a menudo se nos escapa y que, dentro de nuestra limitación histórica, a veces dejamos olvidados en las páginas de los periódicos y revistas sensacionalistas, confirman este calificativo. Guerras crueles, convertidas a menudo en auténticos genocidios: Vietnam, Biafra, Oriente Medio. Guerrillas y contraguerrillas en América Latina. Ocupación violenta de Checoslovaquia por las fuerzas del Pacto de Varsovia. Revoluciones estudiantiles, a veces tan sangrientas como la de México, o tan absolutas, como la de mayo-junio francés. Asesinatos llamativos, como el de Martin L. King o Robert F. Kennedy. Y, so capa de una legalidad hiriente y un orden mitificado, la continua violencia de los pobres y de los oprimidos. La violencia que se hace a los treinta millones de personas que cada año mueren en el mundo por falta de alimentación. La violencia de la discriminación racial (Rodesia, Estados Unidos...), política (España, Grecia, países comunistas...), religiosa (Irlanda...), etc. Año de la violencia, sí, pero porque nuestro mundo, nuestra sociedad actual se funda básicamente en la violencia de los unos para con los otros.

No es fácil intentar una reflexión cristiana (¿teológica?) sobre la violencia. $\mathrm{Y}$ no es fácil, tanto porque el término violencia es de una ambigüedad desconcertante, como porque el cristiano se halla enfrentado a una de las crisis más radicales de toda su historia, y a duras penas logra percibir lo que el auténtico mensaje de Cristo pide de él en nuestros dias y

\footnotetext{
* Texto preparado por Martín-Baró, en 1968, durante sus estudios para obtener el grado de bachiller en Teología en Eegenhoven.
} 
en nuestro mundo. Pero la dificultad del problema no hace sino agudizar la necesidad de una respuesta, quizá no tanto en el plano teórico como en el plano existencial, en el plano de la vida concreta.

La urgencia con que el cristiano se encuentra confrontado con el problema de la violencia proviene de la confluencia de dos fenómenos, posiblemente los más importantes de nuestra época. Por una parte, la toma de conciencia generalizada de que la sociedad en que vivimos es fundamentalmente injusta y, por ende, violenta. Saber que el $85 \%$ de os hombres se hunden en la miseria más horrible para hacer posible el superconfort de un $15 \%$-y la proporción tiende a agudizarse todavía máses algo que golpea rabiosamente la conciencia del cristiano, tradicionalmente tranquilo en su caparazón de ritos y reflexiones piadosas ultramundanas. Por otra parte, el fenómeno llamado de la secularización sitúa al hombre ante el mundo actual, y le recuerda que él y sólo él es el responsable de su estructuración. Así, el cristiano cae en la cuenta de que su fe no le permite aplazar para un más allá problemático la obra que debe realizar aquí, en este momento. Si existe injusticia en el mundo, el cristiano -como todo hombre- es corresponsable de ella. La sociedad de mañana, justa o injusta, será obra de sus manos. En definitiva, el fenómeno de la secularización recuerda al cristiano que su vocación de hijo de Dios no le exime de su tarea como hombre, antes bien la hace más urgente. Por lo tanto, el cristiano no puede en ninguna manera evitar el enfrentamiento con la situación del mundo actual, sino que tiene que adoptar necesariamente una postura y una conducta, consecuente con su realidad de hombre y de cristiano -que es decir lo mismo bajo otro aspecto-, si pretende ser fiel a sí mismo.

Henos, pues, enfrentados con el problema de la violencia. Pero, ¿qué es la violencia? ¿Qué diferencia hay entre violencia y revolución? ¿O son una misma cosa? Demos algunas definiciones, quizá no totalmente satisfactorias, pero que, al menos, nos servirán para emplear con propiedad estos términos a lo largo de estas páginas.

De una manera hoy día generalizada, se entiende por revolución: "E1 cambio producido deliberadamente, rápido y profundo, que afecta a todas las estructuras básicas (políticas, jurídicas, sociales y económicas) y corresponde a una ideología y a una planificación" (Snoek, 1966).

Se diferencia de la evolución por la rapidez y por la intencionalidad del proceso. Así concebida, nada tiene que ver con la cartelada, ni con el golpe político. Implica, en su propio concepto, un elemento de ruptura con el orden vigente y la elaboración de un nuevo orden. La insurrección y la violencia pueden acompañar al movimiento revolucionario, pero no constituyen su esencia (Snoek, 1966). 
Si la revolución implica un cambio radical en los diversos órdenes fundamentales de la vida humana, es importante subrayar como lo hace Swomley Jr. (1967) que la calidad revolucionaria de un suceso no se ha de medir tanto por las intenciones de sus promotores cuanto por el resultado final, es decir, "saber si, en realidad, el orden de cosas ha sido invertido y si se ha realizado un cambio social creador" (p. 9).

Una revolución puede ser violenta o no violenta. Por lo tanto, el problema de la violencia se plantea al nivel de los medios, no de los fines. Ya hemos dicho que violencia es un término sumamente abstracto y de una gran ambigüedad. En efecto, todos los estudios parecen llegar a la conclusión de que no se puede hablar de violencia en general, sino de situaciones violentas. En este sentido, la violencia no es algo de lo que se pueda hablar en abstracto, sino encarnado en una situación concreta. De hecho, y hasta un cierto punto, todos los aspectos de la vida manifiestan violencia: hay violencia tanto en el que mata como en el que se contiene para no matar; hay violencia en el hablar (la formulación en un lenguaje determinado violenta y constriñe el pensamiento), como la hay en el silencio; en la misma dinámica del ser humano hay violencia, y todo crear es al mismo tiempo un destruir (¿no habría que profundizar aquí el sentido profundo de lo que Freud dio en llamar instinto tanático o de muerte?); hay violencia, en definitiva, en toda vida, que se va consumiendo en una continua autoviolencia, para terminar en la gran violencia de la muerte. Si admitimos esta extensión total de la violencia a la esencia misma de lo vital, habremos de admitir también que todo empleo del término violencia será por necesidad convencional -si quiere ser significativo-, y ha de decir relación a un estado o situación concreta.

En nuestros días (desdichadamente) se suele entender púbicamente por violencia todo ataque armado contra el "orden establecido", toda oposición vigorosa a la institución social, sea de la dimensión que sea. Y, en efecto, hay aquí una violencia. Pero reducir el término violencia a toda acción contra el "orden establecido" y sólo a ello, supone un cinismo demasiado interesado (o alienado), que da por supuesto que no existe violencia en la legalidad. Pero -como muy bien señala Ellacuría (1968)hay que desenmascarar la violencia tremenda que se puede ocultar bajo ordenamientos jurídicos admitidos. ¿Quién podrá negar que existe una violencia inhumana, bajo visos de leyes muy cultas, en todas aquellas poblaciones donde sólo una minoría puede disfrutar de una vida digna del ser humano -a costa del hambre, sufrimiento y esclavitud de la gran mayoria? En este sentido, hay que ir mucho más lejos. No es violencia únicamente aquella acción que se realiza con las armas en la mano, sino también toda acción o toda situación que entraña una injusticia. Estamos de acuerdo con Ellacuría (19691) cuando afirma que "la verdadera

\footnotetext{
${ }^{1}$ En el manuscrito Martín-Baró ofrece las siguientes informaciones sobre esta referencia: IV Semana de Teología - Bilbao, octubre 1968, en Hechos y Dichos, Zaragoza, diciembre 1968, p. 1099. A partir de estas
} 
violencia es aquella que oprime derechos humanos, aun dentro de una justificada legalidad, no la que los promueve, usando por necesidad métodos de fuerza" (p. 1099).

Si admitimos esta estrecha dependencia entre violencia e injusticia, se sigue necesariamente una distinción (como lo hacen muchos autores) entre violencia y fuerza. La violencia crea la injusticia, la fuerza es necesaria para salir de ella. Una y otra pueden implicar destrucción, pero la valoración moral es diferente, como lo es en su intención. Si tenemos presente este aspecto axiológico, podemos admitir la definición que J. Freund (citado por Le Guillou, 1968) nos da de violencia, como "la explosión de fuerza que se dirige directamente a la persona o a los bienes de otros (individuos o colectividades) con el fin de dominarlos por la muerte, la destrucción, el sometimiento o la derrota" (p. 54). En esta definición nos permitiriamos únicamente subrayar la palabra dominación, que es la que da la coloración valorativa.

Saquemos la conclusión de que, desde este punto de vista, no se puede definir simplemente la violencia como el empleo de fuerza material o física que afecta la realidad corporal del hombre (Domergue, 1966). Existen numerosas modalidades de violencia, que no parecen afectar directamente la realidad corporal del hombre y que incluso, como la propaganda, le dejan la ilusión de ser libre en su proceder.

La violencia es, pues, una modalidad de relación entre hombres o grupos de hombres, en la cual una de las partes niega a la otra algún aspecto de su realidad humana (de sus derechos en cuanto hombre), creando con ello una situación de injusticia.

Qué sea la no-violencia, se puede deducir claramente de lo dicho hasta ahora. En efecto, la no-violencia será la reacción del hombre (o grupo de hombres) que sufre la injusticia, reacción que no invierte los papeles, es decir, que no responde a la violencia con la violencia, sino que respeta la realidad humana del "agresor".

Evidentemente, puede haber dos tipos de no-violencia: el uno pasivo (cuando el que sufre la injusticia se resigna a ella y no hace nada por cambiar la situación), el otro activo (cuando el que sufre la injusticia busca por todos los medios liberarse de ella, sin crear con su proceder una violencia en sentido inverso). Mientras el no-violento pasivo acepta su situación inhumana, el activo no.

$\mathrm{Si}$ tenemos presente todos estos términos (en lo que respecta a la violencia, convencionales hasta cierto punto), comprenderemos inmediatamente que una revolución puede ser violenta o no violenta, de la

informaciones hemos llegado al texto "Violencia y cruz" publicado en 1969. Por esto, en este momento, se ha hecho una pequeña edición en el manuscrito con la finalidad de ofrecer una referencia más accesible [Nota del Editor]. 
misma manera que lo pueden ser un proceso de evolución o un orden determinado.

Con estas aclaraciones por delante, ya podemos adentrarnos más directamente en nuestro tema.

\section{El mundo y la iglesia}

\section{Estado actual del mundo}

Una mirada sin prejuicios ni intereses establecidos sobre el mundo que nos rodea, sobre la constitución y organización de la sociedad actual, pone en evidencia una situación fundamental de injusticia. Una situación en la que tan sólo una minoría disfruta de todos los bienes de la tierra y de la civilización moderna, mientras que la mayoría se hunde en una miseria realmente increíble. Algunos datos nos mostrarán, mejor que nada, la veracidad de nuestra afirmación.

\section{Alimentación}

Se sabe que tan sólo una tercera parte de la población mundial consume diariamente una cantidad de calorias suficiente para la conservación de la vida humana. Así, según estadísticas de la FAO, se sabe que

De los cincuenta millones de personas que mueren cada año, para cerca de 35 millones la causa de la muerte es el hambre, bien directamente, bien indirectamente, debido a enfermedades que encuentran un terreno propicio en los organismos debilitados por una alimentación insuficiente o mala (Câmara, 1968, p. 64).

\section{Renta per cápita}

Si nos fijamos en los ingresos medios por persona en los diferentes continentes, nos encontramos con los siguientes datos, que van precisando el contorno de lo que se ha dado en llamar "El mapa del hambre" o, en términos más sociológicos, "el Tercer Mundo". 
Cuadro I: Renta per cápita en el periodo 1953-1965 (Toaldo, 1968)

\begin{tabular}{|c|c|}
\hline \multicolumn{2}{|c|}{ Renta per capita en el periodo 1953-1965 (en US\$) } \\
\hline África & 92,00 \\
\hline Asia & 93,00 \\
\hline América Latina & 335,00 \\
\hline Países occidentales no comunistas & 1510,00 \\
\hline Europa & 1100,00 \\
\hline Estados Unidos & 2695,00 \\
\hline
\end{tabular}

Traducidos al lenguaje vulgar, estos datos quieren decir sencillamente que, mientras unas pocas naciones nadan en la abundancia, la gran mayoría de los países (el llamado Tercer Mundo incluye ochenta y ocho) se sumen en una pobreza, cada vez más radical. Este estado de pobreza aumenta paulatinamente por el conocido fenómeno de la explosión demográfica y por la ordenación del comercio internacional, que hace a las naciones pobres cada vez más pobres, y a las ricas cada vez más ricas. Se da el dato tristemente curioso de que,

en el curso del período 1950-1961 los capitales extranjeros investidos en América Latina se han elevado a 9.600 millones de dólares; durante el mismo período las sumas que han vuelto de América Latina a los países prestamistas se han elevado a 13.400 millones de dólares. Por consiguiente, es América Latina la que ha prestado a los países ricos, y el monto de este préstamo a los ricos se ha elevado a 3.300 millones de dólares. Y si se tiene en cuenta lo que las pérdidas sufridas debido al descenso de los precios de las materias primas y de la alza de los precios de los productos manufacturados han alcanzado, en el mismo período, 10.000 millones de dólares, se comprueba en definitiva que los dólares que han ido, durante estos años, de América Latina hacia los países ricos han llegado a la suma de 13.900 millones (Blardone citado en Câmara, 1968a, pp. 64-65).

\section{Educación}

Mientras que en los países desarrollados la educación primaria es obligatoria y generalizada, la secundaria igualmente común para todos, e incluso, prácticamente, todos aquellos que lo desean pueden acceder a la educación superior, en los países del Tercer Mundo no se ha superado todavía ni siquiera la fase del analfabetismo. Así, en América Latina se calcula que el analfabetismo alcanza proporciones de un 40 a $50 \%$ de la 
población (Diaz, 1962). Más concretamente, en Haití la proporción es del $89 \%$, del $71 \%$ en Guatemala, del $68 \%$ en Bolivia, del 56\% en Honduras. Tan sólo cinco países latinoamericanos tienen una proporción de analfabetos inferior al 30\%: Cuba, Costa Rica, Chile, Uruguay y Argentina.

A la vista de todos estos datos -un infimo botón de muestra- cabe preguntarse sobre la sociedad actual, sobre el orden establecido. ¿Qué "orden", qué justicia, qué legalidad es ésta, que condena a la gran mayoría de los hombres a no ser hombres, para que unos pocos puedan disfrutar de todo? ¿Cómo vamos a aceptar un "orden" en el que unos pocos tienen un futuro vital de 70 a 75 años, mientras que los más consideran ya los 25 como la vejez, y los 30 como el dintel de la muerte? (En Irlanda la esperanza de vida es de 76 años o más, mientras que en el Gabón es de 25 años.) ¿Cómo vamos a aceptar un "orden" social en el que se emplean millones de dólares diarios para producir armas destructivas y mantener poderosos ejércitos, mientras se regatea y escatima el centavo del hambriento? “¿Qué orden social?” -se pregunta Dom H. Câmara (1968a, p. 55): "Yo no conozco los países desarrollados; pero en lo que toca a los paises subdesarrollados hay que decir que lo que se llama 'orden social' no es más que un conjunto de injusticias codificadas". Ciertamente, hablar de orden es una ironía, por más perfecta que sea su institucionalización, por más bella que aparezca su codificación legal. Mientras impere en el mundo un tal "orden", documentos como la "Declaración de los derechos del hombre" no pasarán de ser un terrible sarcasmo. ¿Orden establecido? No. Desorden establecido. Un repugnante desorden social.

\section{El papel de la iglesia}

No es fácil entrar a juzgar el papel desempeñado por la Iglesia en esta sociedad desordenada, sin incurrir en demagogia. Nuestro análisis debería comenzar por un reconocimiento de lo mucho que la Iglesia ha realizado en beneficio de los pobres, de los pueblos subdesarrollados. Sin embargo, una apologética eclesiástica constantiniana y mal orientada, ha aireado ya por activa y por pasiva, del lado cristiano, lo que la Iglesia ha hecho, cuidándose muy bien de no hacer la más mínima referencia al cómo lo ha hecho, o a lo que ha dejado de hacer. Tal vez, en los grupos más avanzados, la tendencia hoy es inversa y se tiende a resaltar más bien lo que la Iglesia no ha hecho, olvidando incluso lo que ha realizado. Tendencia bien explicable si se piensa en la urgencia de reconocer los propios pecados -hasta hoy dejados de lado- en vista de un cambio total de actitud, de una conversión. En este sentido trataremos de juzgar la actitud tradicional, no de ciertos cristianos $\mathrm{u}$ organizaciones particulares, sino de la Iglesia institucional, de la Iglesia como cuerpo jerárquico. Y nos fijaremos tanto en el "qué" de esta actitud, como en el "cómo".

Nuestra afirmación es doble (válida en conjunto, aunque admitamos que habria que matizarla): 
a) En cuanto la Iglesia en gran parte se ha olvidado de las inmensas masas de pobres, aliándose con la sociedad establecida y rica, y ofreciendo como consuelo a los abandonados por la fortuna una religión piadosa y un consuelo ultramundano, ha ofrecido efectivamente un opio al pueblo.

b) En cuanto la Iglesia ha tratado de ayudar a los pobres e intentado aliviar su situación, lo ha realizado con una mentalidad caritativa en sentido peyorativo, es decir, con una mentalidad asistencial, paternalista, consagrando con ello el estado de hecho, y cometiendo un grave pecado (objetivo) contra la dignidad del pobre.

Es quizá duro reconocerlo, pero ambas afirmaciones se nos presentan como evidentes. ¿Quién puede negar que la Iglesia ha estado del lado de los ricos, más aún, ha buscado ella misma la riqueza, en amplias regiones de Latinoamérica, por ejemplo? El representante de la Iglesia -el sacerdote- era considerado como una más de las autoridades civiles (de la sociedad establecida), y su doctrina no hacía más que suavizar la injusticia de la situación, ofreciendo al pueblo el alivio de una repartición "ultraterrena" de los bienes más equitativa que la presente. La religión se convertía en una simple droga, en un opio que mantenía al rico en su riqueza y al pobre en su pobreza inhumana. "Bienaventurados los pobres de espiritu", predicaba, mientras buscaba para ella honores y riquezas. "A los pobres siempre los tendréis con vosotros", meditaba, y con ello procuraba aplacar su conciencia. La condena radical de la doctrina comunista en el momento de su aparición, ¿no se debe en gran parte a que la Iglesia se encontraba identificada con el mundo explotador, capitalista?

Pero más triste y evidente es, si cabe, la segunda afirmación. En efecto, cuando la Iglesia ha tomado conciencia de la pobreza que le rodeaba, y de lo injusto de la situación, su postura se ha reducido a una simple ayuda de tipo asistencial, paternalista, buscando incluso en esta ayuda su propio beneficio. Insisto, porque me parece importante, que no se trata aquí de dar un juicio sobre muchos representantes y miembros de la Iglesia, que han llegado a sacrificar sus vidas por estos pobres. No juzgo sobre sus conciencias, sino sobre su actitud objetiva. Y, las más de las veces, ésta no ha hecho sino apagar el fuego de quienes reclamaban justicia con el agua bendita de una caridad paternalista. La Iglesia rica dejaba que sus migajas alimentaran el hambre de la Iglesia pobre. No era cuestión de cambiar la situación -la providencia de Dios había establecido así las cosas-, sino de ofrecer al rico la oportunidad de ejercer sus sentimientos "caritativos". Con ello, el estado de hecho -el desorden institucionalizado- quedaba consagrado, bendito por la Iglesia. Y si algún pobre se atrevia todavia a levantar la voz, después de haber recibido "la caridad", el cristiano (o el sacerdote) rico llegaba a exclamar sorprendido: "Pero, ¿qué más quiere? Es un desagradecido...". 
Con esta doble y triste actitud errónea, la Iglesia se ha convertido históricamente en uno de los elementos estabilizadores de la sociedad capitalista, y en una de sus fuerzas más reaccionarias. Cuando en nombre de Dios se ha bendito por activa y por pasiva este "desorden codificado", ¿quién se atreverá a llevar la contraria a Dios?

Esta Iglesia, verdaderamente comprometida con el mundo, pero en el mal sentido, h sido una auténtica "tumba de Dios". No basta rechazar y condenar las acusaciones que le hace el comunismo. Un auténtico cambio efectivo se impone: una verdadera "metanoia“. Dice Helder Câmara (1968a, pp. 54-55):

Hay que modificar una cierta mentalidad; por ejemplo, la que reduce todo el problema del hambre y de la miseria en el mundo a un problema de asistencia. Los cristianos tienen esta mentalidad que yo llamaré "asistencial" y que cree resolver todos los problemas sociales por la caridad o la asistencia de los pobres. Hay que cambiar esta mentalidad: ipor lo que hay que luchar es por la justicia social! Reconozco que la caridad privada y pública, la asistencia a los pobres, serán siempre necesarias, pues siempre habrá desgraciados, abandonados, fracasados, personas que se han equivocado. Pero un verdadero orden social y cristiano -y los cristianos tienen el deber de instaurar este orden en la vida civil- no puede fundarse sobre la asistencia, sino sobre la justicia.

\section{El cristiano y la politica}

\section{Actitud tradicional}

No pretendemos hacer una historia de la actitud que el cristiano ha tomado ante la política a lo largo de sus veinte siglos de existencia. Es evidente que, en este terreno, las posiciones han sido muy diversas, según las épocas, lugares y personas. Nos limitaremos, simplemente, a reflejar la actitud politica que el cristiano del siglo XX ha adoptado por lo general, quizás movido a ello por una serie de circunstancias históricas, como han sido los movimientos antirreligiosos, la revolución técnica e industrial, el modernismo, y la pérdida del poder político y geográfico de la Iglesia.

Sea lo que sea de las causas que han motivado histórica e intelectualmente su actitud, el hecho es que el cristiano ha mirado con recelo a lo político, las más de las veces se ha vuelto de espaldas a ella y, cuando ha tenido que intervenir, lo ha hecho manteniendo un abismo, una separación total entre sus creencias y su actitud política, ya que su fe -su moral, diriamos mejor- no le ofrecía nada que pudiera orientar su actividad práctica en este terreno (a no ser recelos y condenas). El resultado ha sido que la sociedad civil se ha creado, orientado y fortalecido con independencia absoluta de cualquier tipo de sentido cristiano. Y, 
lamentablemente, alli donde los cristianos como tales han salido de la sacristía, no ha sido más que para reclamar y obtener beneficios y privilegios para la Iglesia. Frente a las demás realidades, el cristiano -con su ausencia o con su anuencia- ha mantenido un conformismo lamentable con el poder establecido, incapaz e impotente para oponerse al poder establecido en sus estructuras fundamentales. Lo que se dice de los cristianos, hay que decirlo también (como regla general) de la Iglesia institucional. Allá donde sus "derechos" no eran heridos, la Iglesia mantenía la sonrisa y la connivencia con el desorden establecido, aunque ese desorden supusiera la esclavitud de los pobres. Pero ¿qué importaba la justicia, con tal de que se pudiera practicar libremente la religión, la única actividad verdaderamente importante del hombre sobre la tierra?

\section{La secularización}

Todo este planteamiento ha sido sacudido desde sus raíces más profundas por el viento secularizador. Dos concepciones principalmente, la de creación y la de historia, han transformado una teología abstracta, ultramundana y teorizante, en una teología concreta, mundana y práctica, que obliga al cristiano a enfrentarse valientemente con las cosas y problemas del hic et nunc (aquí y ahora). Digamos dos breves palabras sobre estas concepciones.

Frente al inmovilismo de la noción tradicional de creación, hoy se ha llegado a una concepción mucho más dinámica y evolutiva. En efecto, tradicionalmente se concebía la creación como un acto de Dios, mediante el cual, el mundo había sido establecido esencialmente tal y como lo vemos. Las cosas, las mismas organizaciones (e incluso las instituciones) habian sido creadas directamente por Dios. Es decir, Dios había creado la naturaleza en sus facetas más diversas, $\mathrm{y}$, por lo tanto, todo lo que había que hacer era encontrar esa naturaleza, definir la esencia de las cosas, y ver qué formas, estados e instituciones correspondian a esa naturaleza. Por todas partes se aludía al concepto de natural, dando por supuesto que una conformidad con esa naturaleza era una conformidad con los designios de Dios.

Por el contrario, hoy día los conceptos de naturaleza y natural se nos presentan como algo muy oscuro y ambiguo. El mundo es una realidad evolutiva, en continuo cambio, tendiente siempre hacia más, y no algo estable y terminado. Argumentar que los cambios son meramente accidentales, pero que las sustancias permanecen, es una argucia escolástica que remite el problema al terreno abstracto. Ahora bien, en el orden concreto no existe una substancia absolutamente independiente de sus accidentes. Por lo tanto una modificación de los accidentes puede llegar a constituir una modificación sustancial. Esto si nos situamos en un plano escolástico, que nos parece totalmente inadecuado. En un plano más realista, la experiencia es evidente. Científicamente nadie puede negar 
hoy el fenómeno de la evolución de las especies, como no se puede afirmar, por ejemplo, que el paso de los homínidos al hombre no hay sido más que un cambio accidental. El mundo es, pues, una realidad en continua evolución.

De ahí surge la necesidad de elaborar una nueva concepción teológica de la creación. Una concepción liberada del estatismo escolástico (sustancias hechas, esencias definidas), de tipo teleológico, que mire más al final (al esjaton) que al comienzo. Las cosas, los seres, no son estados simplemente dados, inmóviles, sino que están en un continuo despliegue de sí mismos. En este sentido, nada está dado definitivamente y, por lo tanto, nada puede ser considerado como un absoluto final. Existe una auténtica autonomía de lo mundano, autonomía que manifiesta precisamente la grandeza de Dios, el "radicalmente otro", que las crea. No existe una creación instantánea, realizada de una vez para siempre: la creación es un continuo hacerse. No hay creación, sino un irse creando (de la misma manera que Teilhard de Chardin afirmaba que no se puede hablar de espíritu, sino de espiritualización).

Ya podemos vislumbrar las graves consecuencias que esta concepción implica para la actividad del hombre. Porque todo lo que haga el hombre sobre esta tierra será verdaderamente un colaborar positiva o negativamente a esa obra de la creación. Si el hombre vislumbra las realidades terrestres en función de un fin, de una utopia, del esjaton cristiano, y no en función de naturaleza o estados ya definidos, se ve obligado a relativizar esas mismas realidades, precisamente porque el único absoluto es Dios. Todo esfuerzo por consagrar definitivamente cualquier realidad terrestre no es más que una idolatría, una divinización idólatra de un ser temporal. Que es lo que, desgraciadamente, ha sucedido en el terreno político. La Iglesia ha idolatrado ciertos tipos de estructuras y organizaciones sociales, considerándolas como establecidas y queridas directamente por Dios. De ahí su despreocupación ante la evolución del tiempo, ante las nuevas exigencias que se iban manifestando a través de la realidad social y humana. De ahí su fixismo larvado, y su incapacidad creativa. De ahí su traición a la labor querida por Dios.

Junto a este concepto nuevo de creación, el factor histórico ha jugado un papel trascendental en la transformación de la teología. En efecto, tradicionalmente se había perdido el punto de vista histórico en las concepciones teológicas, como si Dios e hubiera revelado al hombre fuera del tiempo. Hoy se ha regenerado esta concepción de la Palabra de Dios como realidad histórica, concepción profundamente bíblica. La Palabra de Dios tiene una dimensión temporal y, por lo tanto, humana. Es decir, en cuanto trasmitida al hombre y por el hombre, es una palabra siempre y en todo lugar encarnada, una palabra situada en un tiempo y en un lugar (hasta la culminación definitiva, que fue la Encarnación de la Palabra de Dios: Jesucristo). 
Como la Palabra de Dios, así también la Iglesia, su portadora, tiene una dimensión histórica y, por lo tanto, social. De ahí, una vez más, la imposibilidad de fijar definitivamente la Palabra (dogmas estáticos), o una realización concreta de la Iglesia (estructuras estáticas), como algo absoluto. Tanto la Palabra divina como la Iglesia son realidades que responden a un momento histórico y, por lo tanto, en cuanto concretizadas sujetas a una necesaria evolución. La Iglesia no puede considerarse bajo ningún aspecto como el Reino de Dios definitivo, sino como el pueblo de Dios peregrino que camina por la historia hacia la realización última de la Palabra divina. Por ello, esta realización, que tendrá lugar al final de los tiempos, se va determinando en cada momento de la historia. La Iglesia se debate en una tensión de "ya", pero "todavía no" con respecto al Reino de Dios; de presente sí, pero que en su mismo ser presente está ya exigiendo dinámicamente la realización del futuro. Nunca puede decir sin más la Iglesia: ¡Ya! ¡Al fin! Porque cada meta se convierte en punto de partida en el mismo momento de ser alcanzada. En este sentido, el cristiano se encuentra con la grave responsabilidad de ir respondiendo a las necesidades de cada momento histórico con todas sus energías, aunque siempre con la vista puesta en el ideal final, en el esjaton. Creer que se puede mirar al final dando la espalda al presente es un error grave. Ese final no existe sino en la medida en que se va realizando en el momento presente. De ahí la grave responsabilidad del cristiano frente a toda realidad terrestre.

Tanto la teología de la creación como la de la historia obligan al cristiano a definirse frente a este mundo. Es decir, le fuerzan a comprometerse (s'engager dicen los franceses con una palabra muy expresiva) con las realidades humanas, científicas y sociales, a introducirse en el proceso histórico. No existe posibilidad de escapismo para el cristiano. Precisamente porque cree en un final está obligado a trabajar en el presente, en la creación histórica de ese final.

Muy especialmente hay que incluir en este compromiso el aspecto político, ya que la sociedad se orienta básicamente a través de las fuerzas económico-políticas (la misma economía puede ser determinada en gran manera por el régimen político). Naturalmente, el cristiano tiene que correr el riesgo de poderse equivocar, de escoger erróneamente. Toda opción humana es fundamentalmente ambigua. Como dice Houtart (1968, p. 150), en esto consiste

el misterio del pecado y de la gracia, el misterio de la muerte y de la Resurrección. Y todos nosotros vivimos sumergidos en esa realidad. Esta ambigüedad no es algo que exista fuera de nosotros, en una realidad puramente objetiva. Esta ambigüedad pasa por el centro mismo de nuestro ser; es el dilema de todos los hombres. 
Por ello, toda elección humana supone un riesgo. Pero es más valioso el error en la sinceridad, que el absentismo por un miedo paralizante. En todo caso, la moral tradicional cristiana miraba con tal recelo el sector politico que, a la hora de elegir, el cristiano se encontraba maniatado por las dudas y, o bien lanzaba su cristianismo por la borda en las decisiones puramente políticas, o bien se marginaba como espectador.

Esta actitud debe cambiar radicalmente. Como muy bien dice Michel Rondet (1968, p. 480):

En el combate que le solicita en nombre mismo de la autenticidad de su fe, de su esperanza y de su caridad, el cristiano encuentra diversas ideologias que le proporcionan instrumentos de análisis económico y político, movimientos que le presentan un cuadro posible de acción. ¿Deberá acaso esperar para comprometerse a que se disipe toda ambigüedad sobre los medios elegidos y sobre los fines perseguidos en común? Esto supondría, la mayoría de las veces, condenarse a una inacción cómplice de la injusticia. El cristiano debe escoger a menudo en el estrecho terreno de lo posible el campo y los medios políticos de su fidelidad evangélica. Pero debe guardarse de absolutizar una elección necesaria y contingente. Su compromiso debe ser plenamente leal con respecto a aquellos con quienes combate; pero no puede ser incondicional hasta el punto de conducirle a la idolatría, siempre tentadora en el tiempo del combate, de una ideología o de un movimiento. La referencia a Cristo es para él de tal peso, que le hace libre frente a los medios y caminos que elija (Gal 5, 1-24). Por lo tanto, debe permanecer consciente de ello y manifestárselo a los otros, si es preciso. Esto, no para evitar el riesgo del compromiso, sino para ser auténtico con sus compañeros de lucha y fiel a su fe.

\section{Por una teología de la revolución}

¿Es posible una teología de la revolución?

Numerosos autores se preguntan hoy día si es posible estructurar una teología de la revolución, es decir, dar una fundamentación enraizada en la Palabra de Dios sobre los movimientos sociales revolucionarios. Las respuestas, naturalmente, son muy diversas. Ya veremos algunas de ellas al examinar las diferentes teorías. Señalemos cómo, a partir de la misma revelación cristiana, se puede llegar a conclusiones totalmente distintas.

Así, por ejemplo, para Michel de Certeau (1968) no se puede hablar propiamente de una teología de la revolución.

La teología de la revolución corre el peligro de esconder, bajo una etiqueta nueva, cosas muy viejas y una 
generosidad no demasiado inocente; poniendo una antología de textos bíblicos al servicio de una "profecía" creada a la imagen del presente; incapaz, a causa de eso mismo, de medir el sentido falso que realiza subrepticiamente su reinterpretación del pasado; víctima inconsciente de ese mismo pasado cuando quiere determinar sus compromisos politicos a partir de principios religiosos, se puede convertir en un barniz engañoso. Esta hermosa teología cubriria solamente con palabras lo que cree entender. No habría servido más que a la mala conciencia, encubriéndola; así, demasiados "clérigos", al defender la guerrilla (que cada vez menos se presenta como el camino fundamental de la revolución en América Latina), no hacen más que expresar su malestar, en lugar de deducirlo del análisis económico, social y político de una situación nacional. Por lo tanto, la revolución para el teólogo no es tanto aquello de lo que habla, como aquello en función de lo que debe hablar. Es el acontecimiento que desplaza las sociedades y frente al cual se debe solucionar la interrogante abierta, a través de la experiencia del riesgo y de la muerte, por la palabra de Dios. Pronto tendriamos una teología del alunizaje o de la pesca submarina. La teología no sabría ya ni de qué habla (Certeau, 1968, p. 97).

Por el contrario, para un González Ruiz (1968) la palabra de Dios es una palabra encarnada $\mathrm{y}$, por lo tanto, tiene una implicación social directa. El pecado original hay que concebirlo como una estructura social $\mathrm{y}$, por consiguiente, la redención debe tener asimismo una dimensión social, es decir, que la redención exige una sanatio de las estructuras sociológicas contaminadas por el pecado original. La misma actitud de Jesucristo, al denunciar las estructuras sociales de su tiempo, puede servir de modelo a la actividad política del cristiano y de la Iglesia. Por todo ello, la teología de la revolución para González Ruiz (1968) es, no sólo posible, sino inevitable.

Entre estas dos posturas extremas, existe toda una gama de matices sobre la teología de la revolución. En definitiva, tal vez no sea más que un asunto de palabras, ya que en el fondo aquello que interesa al cristiano actual es una justificación cristiana de su actividad política (y, llegado el caso, revolucionaria). En sintesis -se pregunta Lochmann (1968)- ¿no se trata más de un problema ideológico que teológico?

Personalmente, creemos que no se puede hablar de teología de la revolución en el sentido de que la Palabra de Dios exija directamente al cristiano ser un revolucionario. Como dice Blanquart (1968, p. 142), "si se es revolucionario, no es porque se sea cristiano, sino porque se utilizan ciertos instrumentos racionales que hacen comprender que la revolución es la única solución posible a los dramas y callejones sin salida de la situación social". Habría que añadir a estas palabras de Blanquart el que, 
en un determinado momento histórico, también la fe cristiana puede ayudar a descubrir la falsedad de una determinada estructura social y, por lo tanto, impulsar a la revolución. Es decir, en el cristiano no se puede hacer una separación demasiado tajante entre su ser de hombre situado histórica y socialmente, y su ser cristiano.

Pero si se puede hablar de una teología de la revolución, en el sentido de que la fe cristiana exige al hombre una toma de posición frente a todo tipo de idolatría histórica y, por lo tanto, frente a las estructuras sociales de un momento y lugar determinado. Por ello, hay que subrayar con Metz (1968) que el papel de las "reservas escatológicas" cristianas es el de subrayar el carácter provisorio de todo estatuto histórico de la sociedad, es decir, que toda teología escatológica debe adoptar una actitud críticosocial frente a cualquier tipo de estructuras dadas. En este sentido, el amor de la Iglesia debe ser un factor revolucionario-critico, es decir, debe tener una dimensión propiamente social.

Hecha esta aclaración, examinemos algunas de las respuestas más significativas dadas a nuestro problema, para sacar, al final de este trabajo, las conclusiones más evidentes.

\section{Principales teorias}

\section{Pablo VI}

El término violencia no es, propiamente, ni marxista ni cristiano. Tradicionalmente, el cristiano ha hablado, no de violencia, sino de "insurrección legítima". Pero "el derecho de insurrección no puede ejercerse de manera permanente, sino en condiciones estrictamente limitadas (Bigo, 1968, p. 575). Por lo tanto,

si se llama violencia un estado permanente de guerrilla fuera de estas condiciones, hay que decir que "la violencia no es ni cristiana ni evangélica" (Pablo VI en Bogotá)... En este sentido, si se quiere, hay una condenación cristiana de la violencia (Bigo, 1968, p. 575). tema:

En Populorum Progressio, Pablo VI (1967) aborda francamente el

Hay situaciones cuya injusticia exige en forma tajante el castigo de Dios... Es grande la tentación de rechazar con la violencia tan graves injusticias contra la dignidad humana ( $\left.\mathrm{N}^{\circ} 30\right)$

Sin embargo, ya se sabe: la insurrección revolucionaria salvo en el caso de tiranía evidente y prolongada, que atentase gravemente a los derechos fundamentales de la persona y damnificase peligrosamente el bien común del país- engendra nuevas injusticias, introduce nuevos 
desequilibrios y provoca nuevas ruinas. No se puede combatir un mal real al precio de un mal mayor $\left(\mathrm{N}^{\circ} 31\right)$.

El P. Bigo realiza el siguiente análisis de este párrafo:

1. No es la violencia, sino la insurrección la que puede ser legítima en un caso: el de una "tiranía evidente".

2. El inciso: "salvo el caso..." alude directamente a la doctrina tradicional, expresando una de las condiciones de la insurrección legitima: la tiranía. El pueblo debe estar en legitima defensa contra una tiranía que puede compararse con una verdadera agresión.

3. El Papa no habla de un tirano, sino de una tiranía. Aquí insinúa lo que afirmaron los obispos en Medellin, es decir que la tiranía puede provenir "ya de una persona, ya de estructuras evidentemente injustas" o sea de "una violencia institucionalizada"

4. En el texto de la encíclica, el Papa, mucho más que a la eventual legitimidad, es sensible a los males atroces que provoca toda insurrección, aún legítima.

5. En otro párrafo $\left(n^{\circ} 32\right)$ invita a "transformaciones audaces que renueven radicalmente las estructuras (Bigo, 1968, pp. 575-576).

En su discurso del 24 de agosto de 1968, dirigido a los obispos presentes en Bogotá, el Papa les dice que no pueden "ser solidarios con sistemas y estructuras que encubren y favorecen graves y opresoras desigualdades entre las clases". Pero recalca: "ni el odio, ni la violencia son la fuerza de nuestra caridad" (Bigo, 1968). Fuera de ello, en otros diversos discursos, condena clara y rotundamente la violencia y la revolución.

¿Se puede decir que Pablo VI se contradice en estos discursos con respecto a la Populorum Progressio? El P. Bigo opina que no, sino que, al mismo tiempo que insiste en la condena de la injusticia social, no alude nunca en ellos a la eventualidad de una insurrección legítima, lo que no significa su exclusión. Quizás -dice Bigo (1968, p. 577)- Pablo VI "prefirió no hablar del caso excepcional que mencionaba su encíclica" porque algunos comentaristas, "citando solamente el famoso inciso y olvidando todo el resto, habian presentado sus palabras como un permiso dado y casi una invitación a la violencia".

Comentario: Es muy arriesgado emitir un juicio sereno sobre la enseñanza de Pablo VI en materia de revolución. Mientras que Populorum Progressio es, en este aspecto, bastante clara, sus discursos de Bogotá (a pesar de las explicaciones del $\mathrm{P}$. Bigo) nos parecen decir lo contrario. No es cuestión de hacer filigranas a fin de hacer decir al Papa lo que nadie entendió que dijo. En otras palabras, si sus discursos y afirmaciones pueden salvarse mediante equilibrios escolásticos, su actitud pública junto 
a las autoridades políticas (el poder establecido) no deja duda alguna sobre su sentido obvio. El principio de la insurrección legítima no nos parece apropiado moralmente apara juzgar la conveniencia y valor de la revolución. En todo caso, Pablo VI se muestra demasiado ambiguo en su doctrina sobre la revolución, y parece avanzar a base de contradicciones. Dolorosa comprobación: cuando la Iglesia ha tenido que salir históricamente en defensa de sus "intereses" no ha dudado en justificar moralmente la guerra santa. Pero a la hora de salir en defensa del pobre y del oprimido, y de oponerse al poderoso, parece que -al menos en declaraciones oficiales- le cuesta aplicar el mismo patrón.

\section{A. Z. Serrand}

Traeos a Serrand como representante de una línea teórica, claramente definida en el seno del cristianismo. Serrand hace partir su análisis de una cuádruple distinción terminológica: constreñimiento ("contrainte"), violencia, no-violencia y dulzura. Es constreñimiento:

el uso de cualquier fuerza de presión para provocar en una persona -o en un grupo de personas- un comportamiento contrario, o al menos extraño, a su voluntad inmediata. Llamaremos violencia esa clase particular de presión que, con la misma finalidad, emplea o despliega medios fisicos de presión, apropiadas para disminuir o aniquilar, a menudo con brutalidad, la libertad, la integridad corporal, los bienes materiales. Llamaremos no-violencia ese tipo de acción o, más a menudo de reacción que, sin recurrir a los medios brutales físicos de presión, busca objetivamente neutralizar o cambiar una situación juzgada como insoportable. Será dulzura una renuncia semejante a los medios violentos, que rechaza toda preocupación inmediata por presionar al contrario (Serrand, 1968, p. 26)

Según Serrand (196), la Palabra de Dios profetiza para el fin de los tiempos, de una parte oleadas de violencia, de otra, una época más tranquila (?), en la que una justa presión mantendrá sumisos a los enemigos del Reino de Dios. Pero antes de conocer esta violencia divina, de la que se beneficiarán, los fieles cristianos conocerán la violencia satánica, de la que serán presa. Según Serrand (1968), ante esta violencia satánica, sólo hay dos actitudes posibles para el cristiano: o la huida, o la dulzura. En ningún caso, según Serrand (1968), se debe reaccionar por la violencia, lo que constituirá un testimonio contra los mismos opresores.

Por otra parte, el tiempo evangélico es definido por Jesús como una situación de violencia (Mt 11, 12), es decir, como na exasperación de la vieja lucha contra los poderes malignos. En este tiempo evangélico, los cristianos deben permanecer en el mundo sin ser de él, a fin de dar testimonio. La única lucha que puede mantener el cristiano debe ser 
contra los "poderes malignos". Pero a la violencia que sufra tanto como ciudadano que como cristiano debe someterse. De ahí que al cristiano no le quede más respuesta que la dulzura, ya que su vista se encuentra puesta en un Reino que no se realizará sobre esta tierra.

En definitiva, el Nuevo Testamento nunca anima la revolución o la protesta politica contra las injusticias.

Se diría que para él estas injusticias son, en cierto sentido, fatales, que remite su juicio sobre ellas para después, que por el momento prefiere el orden (...) Su revolución, importada desde lo alto, le hace desinteresarse de cualquier otro tipo de revolución (Serrand, 198, p. 31).

Comentario: Serrand se inclina, a través de una exégesis tradicional, ahistórica y barata, por un pacifismo a ultranza. No explica en qué consisten esos "poderes malignos" de que habla, que nunca llegan a encarnarse de una forma palpable en este mundo. El Reino de Dios no es más que un ideal evasivo, que desliga al cristiano de este mundo, dejando el campo libre al "enemigo". Una interpretación demasiado literal de ciertos pasajes bíblicos le llevan a una concepción de la autoridad y, por consiguiente, de la obediencia, totalmente estática y ahistórica. Permanece en un individualismo espiritualista que, desgraciadamente, ha tenido mucha vigencia en la Iglesia, y la ha conducido a graves errores históricos. Ese supuesto respeto absoluto del evangelio por el orden (el ordendesorden) no está muy en concordancia con el testimonio vital de los profetas -ni tampoco de Jesús-y sí parece contener mucho de idolatría.

\section{Jean Lasserre}

Jean Lasserre se enfrenta con el mundo en su estado actual de injusticia y de violencia, y se pregunta por el papel que el cristiano puede y debe desempeñar en él. En ningún momento admite Lasserre que el cristiano se pueda marginar de la situación histórica en que se encuentra, ya que, si es cierto que Cristo ganó "la primera batalla", y que ganará la última, el problema se sitúa en quién ganará esta segunda batalla planteada a los hombres. Es decir, el problema se cifra en la lucha histórica en la que se halla sumergido el hombre actual. De hecho, los cristianos han aceptado "sin vergüenza un desdoblamiento de la moral" y han encontrado "normal, natural, hacer como ciudadanos u hombres de negocios, lo contrario de lo que hacen en cuanto padres de familia o miembros de la 'Iglesia" (Lasserre, 1965, p. 11). Actitud inadmisible, ya que:

Cristo no se contenta con una parte de nuestro corazón, de nuestra vida, con un sector limitado de nuestras actividades sino que quiere reinar sobre la totalidad de nuestra existencia de hombres, incluida nuestra vida de ciudadanos y nuestras actividades politicas (Lasserre, 1965, p. 12). 
De ahí que el cristiano deba enfrentar con toda seriedad, a partir de la Palara de Dios, la realidad concreta en que vive. Esta actitud se especificará de dos maneras: mediante un testimonio profético, y-llegando el caso- mediante una desobediencia política a las autoridades, mantenedoras de la situación injusta. Es decir, mediante una revolución no-violenta.

Admitida, en una circunstancia histórica determinada (como la actual, por ejemplo), la necesidad de una revolución, el problema que preocupa a Lasserre (1965) es el de los medios que debe usar el revolucionario cristiano. En primer lugar, hay que distinguir entre fuerza y violencia. La fuerza es una presión ejercida sobre el contrario, pero una presión de tipo neutro, mientras que la violencia supone una dominación despiadada del contrario, que lleva en sí misma un elemento destructivo y que manifiesta un desprecio por la persona del rival.

Mientras que la presión se opone a un acto, pasado o posible, considerado como nefasto o criminal, para sancionarle o prevenirle, la violencia se dirige contra la persona misma de aquel a quien pretende reducir a la impotencia, con riesgo de matarle. Mientras que la presión permite e incluso supone el diálogo, en el cuadro de la legalidad, la violencia, por definición, se ejerce más allá de todo diálogo, que rechaza, despreciando igualmente la ley, jurídica o moral, y llegando enseguida a considerar al otro como una bestia malhechora que hay que exterminar, o como na cosa que hay que liquidar (Lasserre, 1965, pp. 0708).

Hay que distinguir también la violencia de la no-violencia, dentro del plano de los medios revolucionarios. Con una comparación brillante, Lasserre (1965) afirma que la no-violencia es a la violencia, lo que la seducción a la violación, con la diferencia de que la no-violencia es algo noble, mientras que la seducción no lo es.

¿En qué consiste la no-violencia, como medio de acción revolucionaria? Según Jean Lasserre $(1965 ; 1968)$, la no violencia tiene cinco rasgos característicos:

1. La no-violencia distingue entre la injusticia y la persona que ejerce la injusticia. Ataca la injusticia misma, no a las personas que son los instrumentos de esa injusticia.

2. Respeta al adversario como ser humano que es, y le considera como interlocutor de un posible diálogo. En este sentido, la lucha noviolenta trata no sólo de vencer, sino también de convencer.

3. La lucha no-violenta expresa necesariamente a una llama dirigida a la conciencia del adversario, cuya libertad respeta absolutamente. "Mientras que la violencia, como la violación, prescinde por reducirle a su interés, la no-violencia busca apasionadamente el convencer a 
sus adversarios, para conducirles a descubrir la injusticia de su empresa, y a que se decidan por sí mismos, libremente, a renunciar a ella" (Lasserre, 1965, p. 204).

4. "Una acción no-violenta implica necesariamente una desobediencia precisa a las leyes del adversario. Por ello, la no-violencia se distingue claramente de la pasividad, de la no-resistencia, y hasta de 1 resistencia pasiva. La no-violencia se concretiza en una acción por el hecho mismo de que se comete una infracción o que se desobedece abiertamente a una ley" (Lasserre, 1965, p. 205). Esta desobediencia se realiza, precisamente, por respeto a uno mismo y por respeto al legislador. Es una manera de apelar a su conciencia sin amenazar su persona.

5. Finalmente, la no-violencia supone una disposición para el sufrimiento, que se sabe de antemano llegará, como efecto de la desobediencia al legislador, sin tratar de responder a su vez al adversario con otro sufrimiento físico o moral (fuera de la molestia que se produce deliberadamente en su conciencia).

Existen, según Jean Lasserre (1965), numerosas razones, tanto de orden espiritual como de orden práctico, por las cuales el cristiano debe rechazar el empleo de la violencia. Por el contrario, existen muchas razones positivas para que el cristiano adopte la no-violencia como arma revolucionaria. Para Jean Lasserre, el motivo fundamental de esta elección está en el carácter esencialmente evangélico de la no-violencia. Cristo es el prototipo del hombre no-violento, cuyo mensaje es profundamente revolucionario, y cuya victoria pasa por la muerte en la cruz. El amor, núcleo de la doctrina cristiana, es incompatible con el empleo de la violencia, mientras que se adecúa perfectamente al uso de la no-violencia.

Comentario: La postura es perfectamente consecuente con el planteo. El problema sería ver si la definición de violencia no es demasiado artificial o si, en otras palabras, no se puede dar una violencia amorosa. En efecto, para Lasserre se pasa de la fuerza (admisible) a la violencia (inadmisible) en el momento en que se desprecia a la persona del adversario (Lasserre, 1965). ¿No es concebible, sin embargo, una violencia sin este desprecio? ¿No puede darse una situación en la que, el estado de alienación del opresor sea tal, que sólo una acción violenta constituya una llamada a su conciencia y, a la vez, el único camino expedito para el restablecimiento de la justicia? En todo caso, si es cierto que una justicia sin amor no es cristiana, también es cierto que no puede haber verdadero amor donde no reina la justicia. En este sentido, podría darse una situación donde la búsqueda del amor presuponga una violencia, instauradora de la justicia. Siempre, claro está, que no traspase sus límites de medio provisional. La vida no es el valor máximo, aunque sí el valor fundamental. En un conflicto de valores, podría llegarse a la situación de tener que matar por amor para hacer reinar la justicia. Aunque, juzgando con realismo, es 
difícil que una acción violenta continuada pueda conservar en el que la realiza un clima psicológico de amor. Y este es el punto fuerte de Jean Lasserre.

\section{Martin Luther King}

No es necesario subrayar la personalidad de Martin L. King, mártir de la no-violencia, premio Nobel de la paz, y una de las figuras cristianas más extraordinarias de nuestro tiempo. Él ha sido la cabeza y el motor principal del movimiento por los derechos cívicos del negro en Estados Unidos, movimiento que ya cuenta en su haber con numerosas victorias.

Para Martin L. King el problema se plantea al enfrentar las exigencias evangélicas con la realidad social actual. En efecto:

el evangelio bien comprendido interesa a la totalidad del hombre, no sólo a su alma, sino también a su cuerpo, no sólo a su bienestar espiritual, sino también a su bienestar material. Una religión que se diga preocupada por las almas de los hombres y que no lo esté igualmente por las chabolas que les condenan, las condiciones económicas que les estrangulan y las situaciones sociales que les paralizan, no es más que una religión espiritualmente moribunda (King, 1968a, p. 225).

Por otra parte, una mirada al mundo que nos rodea nos hace comprender inmediatamente la existencia de un desorden social institucionalizado. Un desorden que Martin L. King encuentra en su propia nación, los Estados Unidos de Norteamérica. Como negro, debe respirar "en una atmósfera donde las falsas promesas son una realidad cotidiana, donde la realización de los sueños es aplazada cada noche, donde la violencia hacia los negros se ejerce impunemente y constituye incluso un modo de vida" (King, 1968b, pp. 36-37). La segregación, ya no legal, pero no por ello menos real, se extiende a todos los planos de la vida: trabajo, alojamiento, educación, vida religiosa... Lo más desdichado de este desorden es precisamente su institucionalización social, su consagración como orden establecido. De ahí que los más peligrosos adversarios de la justicia "no sean el fanático del Ku-Klus-Klan, o de la John Birch Society, sino más bien el blanco liberal, más preocupado por el 'orden' que por la justicia, más defensor de la tranquilidad que de la igualdad" (King, 1968b, p. 107).

Este desorden establecido, evidente en la nación más desarrollada del mundo contemporáneo, se hace todavía más estridente al contemplar el conjunto de naciones de todo el mundo. En este sentido, Martin L King, como norteamericano, reconoce su propia falta:

Nosotros, occidentales, no debemos olvidar que los países pobres lo son más que nada porque notros les hemos 
explotado a través de un colonialismo político o económico. Los americanos en particular deben ayudar a su país a repudiar su neo-imperialismo económico (King, 1968c, p. 96).

Contraponiendo este estado del mundo con la exigencia evangélica, Martin L. King llega a la consecuencia de que es necesario realizar una revolución, a escala nacional primero, a escala mundial después. Si el evangelio, enfrentado a esta situación de desorden que reina en el mundo, no tiende a cambiarlo, es falso. El cristiano, la Iglesia entera como institución deben estar por la revolución. Esta revolución, para que sea evangélica, debe ser na revolución constructiva, una revolución de amor.

El amor que no se preocupa de su deuda de justicia no merece tal nombre. No es más que un afecto sentimental, como el que se tiene a un animal familiar. En el mejor sentido del término, amar es hacer aplicar la justicia (King, 1968b, p. 109).

De hecho, Martin L. King encontró que este amor se lo inspiraba Cristo, y así pudo afirmar de toda su acción que estaba imbuida por el espíritu de Cristo.

Ahora bien, a la hora de realizar esta revolución de amor, no hay que olvidar que una revolución se mide por sus efectos, y no por sus deseos. En este sentido, King comprendió que debía elegir los medios más eficaces para llevar a cabo su revolución (su lucho por los derechos cívicos del negro en Estados Unidos). Es precisamente su deseo de eficacia lo que lleva a King a rechazar la violencia y a escoger el camino de la no-violencia:

Ser eficaz, tal es uno de los problemas esenciales del negro que quiere conquistar su libertad. ¿Cómo hacer para llegar al término tan deseado? (...) Es un hecho innegable, una verdad inexorable, que toda tentativa de los negros para librarse de su opresor por medio de la violencia está avocada al fracaso (King, 1968b, p. 71)

Por ello "no tenemos más que una arma para luchar contra los retrasos, la duplicidad, el 'tokenismo' y el racismo: la acción no-violenta masiva y las elecciones" (King, 1968b, p. 154). La no-violencia no es pasividad ni violencia, sino una síntesis de las dos.

De acuerdo con el método persuasivo, admitimos que no hay que destruir por la violencia ni la vida ni la propiedad de nadie, pero, de acuerdo con los partidarios de la violencia, afirmaremos que hay que obrar contra el mal. Así evitaremos la falta de resistencia del primero y el exceso del segundo. La resistencia no-violenta nos permite rechazar el mal para transformarle en bien, sin por ello acudir a la violencia (King, 1968b, p. 154). 
La única violencia de la no-violencia (su fuerza) consiste en "hacer presión sobre las autoridades para que cedan a las exigencias de la justicia" (King, 1968c, p. 32), una presión sobre "las estructuras de las que se sirve la sociedad" (King, 1968c, p. 92). Por lo demás, la acción noviolenta constituye una llamada a la conciencia pública, puesto que hace salir a la luz la violencia establecida, la hace salir a la calle, e incita así al ciudadano medio y a la opinión mundial a una reflexión sincera. "Es preciso que los liberales blancos comprendan que no es el oprimido quien crea la tensión al luchar por sus derechos. El no hace más que poner en evidencia una realidad subyacente" (King, 196b, p. 110).

Según King (1968c, p. 51) "el verdadero valor de la no-violencia consiste en que nos ayuda a ver el punto de vista del enemigo, a escuchar sus preguntas, a conocer el juicio que tiene sobre nosotros", es decir, que posibilita un auténtico diálogo. King admiraba los efectos extraordinarios de la revolución no violenta de Gandhi en la India, y aspiraba a realizar algo análogo en los Estados Unidos. Por lo demás, esta lucha no-violenta a escala nacional (y de la que King terminó siendo mártir), debe extenderse al mundo entero, a fin de hacer reinar la justicia (King, 1968c).

Muy importante para Martin L. King es el papel que la Iglesia como institución debe realizar en esta acción revolucionaria.

Como entidad, la Iglesia (...) ha concedido a menudo su bendición a un estado de cosas que había que denunciar y ha confirmado un orden social que había que reformar. Por ello, la Iglesia debe ahora confesar sus faltas, reconocer que ha sido débil y que ha vacilado en su testimonio y faltado a menudo a su vocación de servicio (King, 1968b, pp. 116117).

En otras palabras, "corresponde a la Iglesia tomar la dirección de la reforma social. La Iglesia debe descender a la arena y combatir para salvaguardar la santidad de su misión y conducir a los hombres por el camino de la verdadera integración" (King, 1968b, p. 120). Si no lo hace, la Iglesia habrá fracasado en su misión de portadora del mensaje evangélico, y se convertirá en un "club social anacrónico" (King 1968b, p. 120).

Comentario: No se puede juzgar a Martin L. King desde un plano puramente teórico. Para él la teoría estaba encarnada en la acción misma. Sin embargo, es de alabar la sinceridad evangélica de su compromiso, que le hizo vivir personalmente lo que consideró como exigencia cristiana, y que le llevó a morir en el campo de batalla. Es interesante subrayar cómo las dos razones fundamentales por las que King rechaza la violencia no son de tipo bíblico: la eficacia y la convicción de que sólo el amor puede engendrar la paz y la justicia. Muy importante es su concepción del papel de la Iglesia en la acción revolucionaria. Para él, este papel es consecuencia de dos motivos: 1) el evangelio se dirige al hombre concreto; 2) la Iglesia debe reparar el mal que ha hecho al haber bendito $y$ 
consagrado el desorden establecido. Una y otra razón abonan la trascendencia que tiene el aspecto histórico del mensaje divino. Es decir, la concepción histórica de la Palabra de Dios lleva al cristiano y a la Iglesia a constituirse en oponentes de todo desorden establecido, sea cual sea.

\section{Helder Câmara}

El planteamiento de Monseñor Helder Câmara es en todo semejante al de Martin L. King. También para él el problema se sitúa en el encuentro entre la Palabra de Dios y la situación de desorden de nuestro mundo (para él, la situación de miseria e injusticia existente en el Brasil).

¿Cómo olvidar que la vida divina es anunciada a auditores que viven en condiciones inhumanas? (...) Insistir en una pura evangelización espiritual equivaldría a dar en breve plazo la idea de que la religión es una teoría desplegada de la vida, incapaz de unirse a ella y de modificarla en lo que tiene de absurdo y de falso. Sería, entre otras cosas, dar aparentemente razón a quienes mantienen que la religión es la gran alienada y la gran alienadora, el opio del pueblo. Al evangelizar en nombre de Cristo regiones como la nuestra, se llega a una plena humanización (Câmara, 1968a, p. 24).

Es evidente que en el mundo subdesarrollado existe un estado escandaloso de violencia, socapa de legalidad. "Las masas en situación infrahumana son violentadas por los pequeños grupos de privilegiados, de poderosos... ¡El orden-desorden! (Câmara, 1968a, p. 158).

Ante esta confrontación evangélica con la sociedad actual, se impone la necesidad de la revolución. Y esto precisamente en nombre del cristianismo, que nos compromete con el hombre concreto. "Si nosotros, los cristianos de América Latina, asumimos nuestra responsabilidad frente al subdesarrollo del continente, podemos y debemos ayudar a promover cambios profundos en los dominios de la vida social particularmente en la política y en la enseñanza" (Câmara, 1968a, p. 155).

Revolución, pue, a escala nacional, liberando al pobre de su esclavitud y al rico de su alienación. La primera labor revolucionaria que se impone es la "concientización", tanto del rico (despertando su conciencia) como del pobre (haciéndole consciente de sí mismo y de su situación), del poderoso como del miserable, "pues si las mentalidades no llegan a cambiar en profundidad, las reformas de estructuras, las reformas de base, quedarán sobre el papel, ineficaces" (Câmara, 1968a, p. 163). Monseñor Câmara insiste mucho sobre esta toma de conciencia en los países desarrollados, donde parecería que las cosas ya marchan bien. En efecto, también os países de la abundancia "tienen necesidad de una revolución cultural que aporte una nueva jerarquía de valores, una nueva visión del mundo, una estrategia global del desarrollo, la revolución del 
hombre" (Câmara, 1968a, p. 163). Revolución, por lo tanto, a escala internacional, puesto que:

esta revolución social no será posible en el mundo subdesarrollado más que si el mundo del progreso tiene la humildad de comprender y de aceptar el hecho de que la revolución social en África, en Asia, y en América Latina presupone necesariamente una revolución social en Europa y en América del Norte (Câmara, 1968a, pp. 98-99).

Así, por ejemplo, "no haremos más que jugar al desarrollo en tanto que no obtengamos una reforma profunda de la política internacional del comercio" (Câmara, 1968a, p. 42).

Ahora bien, esta revolución ha de ser una revolución de amor ya que "sólo el amor es creador. El odio y la violencia no sirven más que para destruir" (Câmara, 1968a, p. 42). Una revolución de amor que debe estar inspirada por el mensaje evangélico: "Es preciso que el cristianismo nos inspire la mística de servicio para que, progresando en nuestro desarrollo, no nos volvamos egoístas ni violentos" (Câmara, 1968a, p. 14).

Es este espíritu evangélico, pero también la urgencia y la necesidad de eficacia, lo que determina la elección de los medios. Y, hoy, por hoy, el único medio viable de acción revolucionaria para América Latina es el de la no-violencia.

Nosotros, cristianos, estamos del lado de la no-violencia, que no es ni mucho menos una elección de debilidad ni de pasividad. La no-violencia es creer, más que en la fuerza de las guerras, de los asesinatos y del odio, en la fuerza de la verdad, de la justicia, del amor... Pero la opción por la no-violencia si por una parte se enraíza en el Evangelio, se funda también en la realidad. ¿Queréis realismo? Entonces yo os digo: Si en no importa qué parte del mundo, pero sobre todo en América Latina, una explosión de violencia debiera estallar, podéis estar seguros de que, inmediatamente llegarán los Grandes -incluso sin declaración de guerra- las SuperPotencias estarán allá y tendremos un nuevo Vietnam (Câmara, 1968a, p. 162; cfr. También, 1968b).

También para Monseñor Câmara, como para Martin L. King, la Iglesia debe jugar un papel importante en este movimiento revolucionario. En efecto:

la Iglesia está llamada a denunciar el pecado colectivo, las estructuras injustas y rígidas, no solamente juzgándolas desde fuera, sino incluso reconociendo su propia parte de responsabilidades y faltas. La Iglesia debe tener el valor de sentirse responsable al mismo tiempo que los demás de este pasado y, para el presente y el futuro, hacer prueba de una solidaridad más grande (Câmara, 1968a, p. 129). 
Dentro de la Iglesia, tanto la jerarquía, como los sacerdotes y laicos, deben participar en la revolución. Nadie puede rehuir sus responsabilidades. Es interesante observar, a este propósito, cómo Monseñor Câmara concreta en diversos puntos la labor que debe realizar la jerarquía, siempre tan temeroso de enfrentarse con los poderosos" (Câmara, 1968a, p. 68).

Comentario: Es admirable la capacidad de Monseñor Câmara de vislumbrar la complejidad del problema de la injusticia, y su sensibilidad práctica para concretar y realizar puntos de acción realista (Câmara, $1968 b ; 1968 c ; 1968 d)$. Por otra parte, aunque juzga la no-violencia como evangélica, admite la posibilidad de que un cristiano llegue a juzgar la violencia como necesaria, y respeta su conciencia. "Personalmente yo prefiero mil veces que me maten a matar" (Câmara, 1968a, pp. 161-162). Es muy importante el reto que Monseñor Câmara lanza a la moral cristiana, al desenmascarar una serie de principios que justifican aparentemente situaciones abominables: principios como el del valor del orden, la propiedad privada y la dignidad humana que esconden a menudo la injusticia, la explotación o la defensa de intereses inconfesables ( Câmara, 1968a). Las dificultades que afronta hoy día el movimiento de Helder Câmara contra la dictadura militar imperante en el Brasil y el neofascismo de un cristianismo paternalista y explotador, muestran hasta qué punto su acción es auténtica y ha puesto el bisturí en la llaga.

\section{Michel Blaise, o.f.m.}

Para Blaise (1966) enfocar el problema de la violencia a partir de los movimientos armados de América Latina es plantearlo al revés. De hecho, la violencia no es un problema sino un hecho, un proceso en el que unos ejercen la violencia (los ricos) y otros la sufren (los pobres). Por lo tanto, hay que partir de la comprobación de un estado actual de violencia legalizada. Son los ricos quienes hacen de la violencia un problema (de la violencia contra el orden-desorden), porque afecta sus intereses propios.

Tradicionalmente los católicos se han opuesto a la violencia en nombre de la persona humana (Blaise, 1966). Pero esta postura católica, ¿proviene del evangelio o de otras motivaciones ajenas a la fe? De hecho, una cierta concepción de la Iglesia, que erige en fin la institucionalidad jerárquica -lo que no es más que un medio histórico de la Iglesia- le ha llevado a comportarse como un reino de este mundo, y a solidarizarse así con un orden que favorecía o toleraba esta pretensión eclesiástica. La violencia de los pobres se presenta entonces como una amenaza contra la institución de la Iglesia.

Por otra parte, la Iglesia ha buscado a menudo una justificación teológica para conductas puramente humanas. Asi, ha llegado a hacer de la fe una defensa del orden establecido; del amor a la persona, una 
disculpa para sostener situaciones injustas; de la caridad, un sistema paternalista y apologético. En estas circunstancias, la moral se convierte en una defensa de la institución y la ley se hace el instrumento privilegiado de la autoridad. El fiel busca la seguridad en el legalismo, sujeto siempre al dictamen del clero (clericalismo). El legalismo engendra a su vez el individualismo y el idealismo utópico, alejando al cristiano -presa de un formalismo paralizador- de las realizaciones temporales: la fe se convierte en un opio.

Cristo murió a manos de los ricos, de los establecidos socialmente. Su muerte tiene un carácter político, ya que su doctrina ponía en peligro las estructuras político-religiosas de los poderosos. Por desgracia, han sido los cristianos quienes, a lo largo de la historia, se han alineado de parte de los ricos, en contradicción expresa con la voluntad de Cristo.

La Iglesia admite la violencia en caso de una tiranía evidente. E1 problema que se plantea a todo católico es cuándo se da la tiranía. Por desgracia, los moralistas ponen tales y tantas condiciones que, para cuando hubiera podido dar una respuesta a tales condiciones, el cristiano se encontraría con que ya era tarde. Y, en todo caso, dificilmente podría superar el sentimiento de estar haciendo algo malo que le dejaria un tal proceso.

Sin embargo, la violencia supone una singularidad peculiar, ya que cada situación de violencia es diferente. A menudo sólo se puede dar un juicio sobre ella después de realizada. En este sentido, habriamos que propugnar, no una moral de situación, sino una moral en situación (Oraison). No es cuestión de justificar la violencia por el recurso a la legítima defensa -lo que sería oponer el amor al prójimo al amor propio y, por lo tanto, una concesión al egoísmo. Lo que está en juego en las situaciones de violencia es un dilema entre el amor al prójimo y la justicia, dilema no de conciencia, sino de situación social. Es decir, es la situación de la sociedad actual la que puede conducir en ocasiones a la disyuntiva entre la justicia y el amor al prójimo, un dilema entre dos valores auténticamente evangélicos. Ante esta colisión de valores, si el cristiano opta por la violencia en favor de los pobres, no escoge la violencia por sí misma. Lo que escoge es la justicia. Y, al usar la violencia, lo hace consciente de que se trata de un medio extremo y relativo. Con ello, opta por un mundo en el que la justicia y el amor podrán ir a la par.

Comentario: Es muy valioso el enfoque histórico y concreto del problema de la violencia, aunque quizá ésta quede vagamente definida. Lo más valioso de Blaise (1966) es el planteo moral: se considera cómo, en una situación concreta, dos valores evangélicos pueden entrar en colisión, sin que sea posible eludir el dilema. Lo cual supone una relativización sana de la moral, relativización por supuesto en función de Cristo, que llama al cristiano en su vida concreta. Es el principio de la "ponderación de bienes" expuesto por Schüller (1966). 
Olivier Maillard, o.f.m.

Para Maillard (1968), la primera evidencia es de orden práctico, ya que:

tomamos conciencia de la necesidad, de la urgencia, de la envergadura y de la radicalidad de la revolución a partir de conocimientos humanos y no sólo a partir de una ideología. Precisamente porque me encuentro ante problemas de orden económico, politico y social (...) busco una solución y llego a la consecuencia de la necesidad, urgencia, envergadura y radicalidad de la revolución (Maillard, 1968).

Por revolución entiende Maillard (1968) lo mismo que nosotros, es decir, una situación provisional que "produce de manera deliberada, rápida y radical un cambio que alcanza a todas las estructuras de base jurídica, politica, económica, social y cultural, y que corresponde a una ideología y a una planificación". Existe, sí, un elemento de ruptura, pero la violencia no constituye un elemento esencial de la revolución.

Esta toma de conciencia en el plano del conocimiento humano acerca de la necesidad de una revolución, representa un proceso que para nosotros es idéntico, evidentemente, al proceso de nuestra fe (...) puesto que son la justicia, la paz y, en definitiva, la ciudad fraternal lo que están en juego (Maillard, 1968).

¿Cuáles son los móviles y límites de la revolución? Para poder conocerlos, dice Maillard, hay que entender primero el sentido con que se emplean ciertos términos. Porque, ¿qué significa hoy día amar realmente al hermano?

Yo entiendo, no solamente amar al pobre que se encuentra en la miseria, sino también al rico que nada en la opulencia (...) Y precisamente el mor más grande que yo puedo tener hacia el rico es el de oponerme a su riqueza (Maillard, 1968)

Esa riqueza que supone una injusticia social. No puede haber, pues, amor sin justicia. Mas la justicia implica a su vez algo más que dar pan al hambriento. La justicia es "el derecho a ser un hombre, a ser responsable" (Maillard, 1968), con todo lo que esto lleva consigo. Sólo donde reina la justicia, sólo donde todo ser humano puede realizarse como persona es posible una verdadera paz. Así "para nosotros la paz se encuentra al término de la justicia" (Maillard, 1968), y no antes. Para llegar a este punto nos queda todavía un largo camino por recorrer. Es el camino que pretende realizar la revolución. Estos tres términos, amor, justicia y paz, 
definen, pues, cuáles son y deben ser los móviles y los límites de una auténtica revolución.

Una vez comprobada la necesidad de na revolución, hay que pasar a la acción. "No existe un paso a la acción sin una elección política" (Maillard, 1968). Por lo tanto, el cristiano que quiera luchar por la justicia debe realizar una opción política. "Sólo a través de una realidad variada y compleja debemos intentar plantear las elecciones politicas, no porque sean un fin en sí mismas, sino porque son un medio de progreso hacia la justicia" (Maillard, 1968). Esta elección, hoy día, parece que tiene que ser de signo socialista (lo que no quiere decir necesariamente que haya que integrarse a un determinado partido socialista ya constituido).

En cuanto a la elección de medio para llevar a cabo la revolución, no se puede hacer de una vez por todas. Dice Maillard (1968): "Para mí esta elección de medios constituye una toma de conciencia en cada instante de la acción de la manera como se la está desarrollando". En este sentido, el cristiano no se confronta con la violencia en general, sino con determinadas situaciones de violencia. Y, si se profundiza un poco el análisis, se encuentra con que no hay situación humana que esté totalmente libre de violencia. El problema no es pues la violencia como tal; el problema es cómo asumirla desde el interior mismo de la situación violenta. Por ello hay que rechazar las reflexiones puramente teóricas, como la de que "la violencia engendra la violencia". Si esto fuera cierto, el mundo ya no existiría (como consecuencia de la prolongación creciente de las guerras mundiales).

"La no-violencia es para mí un camino fundamental, pero es posible que, en casos extremos, no sea el único" (Maillard, 1968). El cristiano, que debe optar por la revolución, ha de escoger personalmente el camino que considere más adecuado para llevarla a cabo. Pero, en todo caso, sin olvidar que "la vocación del cristiano consiste esencialmente en ser la fuerza de oposición" (Maillard, 1968).

Comentario: Más o menos semejante a Blaise, ya que percibe el conflicto entre justicia y amor. Concede na importancia primordial a la acción misma, y procura despejar las incógnitas que tradicionalmente han paralizado al cristiano. Es importante la afirmación sobre el juicio de moralidad que se hace sobre la elección de medios, siempre condicionada, ya que se hace desde el interior mismo de una situación violenta.

\section{Richard Shaull}

Para Shaull (1966), la historia de Occidente ha sido la historia de la revolución. "La mayoría de los movimientos más importantes hacia una sociedad más humana han sido resultado de estas revoluciones" (Shaull, 1968a, p. 1). Por desgracia, la Iglesia ha desempeñado por lo general un papel retrógrado. Se pregunta Shaull (1968a, p. 2): “¿Es que la misma 
naturaleza de la fe cristiana nos obliga a situarnos en favor del orden? ¿O tal vez nos ofrece elementos para la comprensión de una situación revolucionaria y la participación en una lucha por la reconstrucción social?" De hecho, es un axioma que:

nuestra herencia judeo-cristiana superó la concepción dominante de la historia como un proceso cíclico. En su lugar, introdujo la idea de que la existencia histórica del hombre se movía paulatinamente hacia un fin, y este fin era nada menos que la creación de una humanidad nueva, una nueva posibilidad de plenitud humana dentro de un orden social nuevo (Shaull, 1968a, p. 2).

Mas esta afirmación esperanzadora no nos da la clave del proceso histórico. Teológicamente se pueden afirmar dos cosas:

1. "En la perspectiva de la fe cristiana, la historia humana es la historia de un proceso dinámico de liberación" (Shaull, 1968a, p. 4). Por una parte, las instituciones humanas pierden su carácter sagrado ante las palabras de Jesús: "El sábado fue hecho para el hombre, y no el hombre para el sábado". Por otra parte, el cristianismo revolucionó la concepción según la cual la sociedad humana era una mezcla de humano y divino (concepción ontogrática). Es decir, el cristianismo aportó una desacralización de la concepción social. "Es este contexto, la acción redentora de Dios en el mundo se entiende como un proceso continuo de liberación humana" (Shaull, 1968a, p. 4). De ahí que el hombre esté obligado a tomar el destino en sus manos. Esta voluntad de configuración del futuro la encuentra Shaull en el corazón de los nuevos movimientos revolucionarios del Tercer Mundo. "Y si en el núcleo de la acción de Dios se encuentra el transformar y enriquecer la vida humana y el llenarla de sentido, deberiamos sentirnos intimamente identificados con esta lucha; la consecución de este objetivo debería ser nuestra preocupación central como cristianos de nuestro tiempo... Nosotros creemos en la acción redentora de Dios en el mundo. Vemos esta acción manifestada en estas luchas nuevas, y no tenemos más remedio, como cristianos, que apoyarlas y colaborar con ellas" (Shaull, 1968a, p. 4).

2. "La narración bíblica introduce un segundo elemento en nuestra compresión del proceso histórico: la historia progresa hacia adelante, pero no hacia arriba, debido a que continuamente la acción de Dios por la liberación del hombre encuentra dificultades y obstáculos. (...) En este contexto, la historia progresa a saltos, cada vez que el poder de un orden antiguo es derribado, a fin de que pueda surgir uno nuevo" (Shaull, 1968a, p. 5). Desdichadamente, los que están en el poder se aferran al orden antiguo, incapaces de 
responder a las nuevas demandas. El cristiano debe ser consciente de esta realidad antes de definir sus responsabilidades en el trabajo por una reconstrucción social.

Frente a la realidad actual, ¿será la violencia la única alternativa posible, capaz de hacer progresas la acción de Dios en el mundo? Shaull sólo ve una posibilidad diferente, y ésta es que "los cristianos y la Iglesia se conviertan en la fuerza catalizadora en el desarrollo de un nuevo tipo de oposición al movimiento actual y a las estructuras del poder" (Shaull 1968a, p. 11).

Comentario: Shaull concede una gran importancia al aspecto histórico de la fe cristiana. Su concepción de la historia como camino hacia la realización del Reino de Dios se basa en una teología actual de la creación. Es muy interesante ver que esta realización se concretiza, para Shaull, en una progresiva humanización. Ahora bien, ¿es esta visión específicamente cristiana? $\mathrm{O}$ ¿puede ser compartida con cualquier sano humanismo? El papel del cristiano y de la Iglesia como catalizadoras de las fuerzas dinámicas en la sociedad es un punto muy valioso en la teoría de Shaull.

\section{Camilo Torres}

La figura de Camilo Torres es demasiado conocida como para insistir aquí sobre su personalidad y vida. Anotemos, sin embargo, cómo, de una manera semejante a Martin L. King, en Camilo Torres la teoría va inseparablemente ligada a la acción y cómo, también él, cayó víctima de su generosa lucha contra el desorden establecido.

Es muy importante subrayar la unión total que hay en Camilo Torres entre su cualidad de sacerdote católico y de sociólogo. La ciencia y la religión no son en él dos campos discordantes, sino dos facetas complementarias de su realidad humana. Un hombre para quien la idea no sirve sino en función de su realización vital. La ciencia le lleva a la comprobación del desorden establecido; la religión le exige un amor efectivo para con los hombres, amor que no se puede realizar sino en una sociedad más justa. A ciencia le añade que esa sociedad más justa, donde el amor fraterno exigido por el cristianismo pueda ser una realidad, sólo podrá alcanzarse mediante la revolución. He ahí, brevemente expuesta, la vida revolucionaria de Camilo. Una selección de algunos de sus principales escritos nos mostrará, mejor que nada, este proceso (Torres, 1968).

En un estudio sobre el problema de la violencia ${ }^{2}$ en Colombia, del 10 de marzo de 1963, escribe Camilo:

\footnotetext{
${ }^{2}$ La violencia en Colombia es un fenómeno peculiar, originado por las luchas entre los grandes partidos políticos (Liberal y Conservador), a raíz del asesinato del líder popular Gaitán. No se trata, pues, propiamente de la guerrilla como tal, aunque actualmente haya evolucionado hacia ella (Nota de IMB).
} 
En los países no industrializados, la pequeña minoría que detenta el poder constituye un grupo bastante cerrado y que tiene el grado más elevado de seguridad en el seno de la sociedad. El único medio de perder esta seguridad sería el cambio de estructuras, que originaría la pérdida del control social (Torres, 1968, p. 151).

Son muy importantes, para su futura evolución, las dos comprobaciones de tipo social que hace Camilo en el mismo estudio:

1. Se puede decir que la violencia ha constituido el cambio socio-cultural más importante en los campos colombianos desde la conquista española. Por su mediación, las comunidades rurales se han integrado en un proceso de urbanización, en sentido sociológico, con todo lo que eso implica: división del trabajo, socialización, mentalidad de cambio, despertar de la curiosidad social y utilización de los métodos de acción para obtener una movilidad social a través de caminos previstos por las estructuras existentes, contactos socio-culturales. La violencia ha establecido igualmente los sistemas necesarios para la estructuración de una subcultura rural, de una clase campesina y de un grupo de presión constituido por esta clase, de tipo revolucionario.

2. Aunque es muy dificil hacer predicciones, es muy poco probable que los cambios de estructuras puedan ser realizados por la iniciativa única de la clase dirigente actual (Torres, 1968, p. 156).

E1 5 de mayo de 1964, Camilo ve ya como un imperativo urgente en la realidad política de Colombia la creación de un grupo de presión. En septiembre de 1964, en un trabajo titulado "La revolución, imperativo cristiano", escribe Camilo:

En el mundo actual, es imposible ser cristiano sin tener conciencia del problema de la miseria material. Y si el problema de la miseria material exige el concurso de todos los hombres, resulta que, fuera del caso de una vocación especial o de circunstancias personales excepcionales, los cristianos no pueden sustraerse a las obras exteriores y materiales. Como política de conjunto, el apostolado debe orientarse por prioridad hacia las obras materiales en favor del prójimo, para situarse en una perspectiva de caridad efectiva y actual (Torres, 1968, p. 79).

En el mismo escrito realiza ya una fuerte crítica de la Iglesia institucional colombiana:

A través del poder económico, los poderes cultural, político y militar, la clase dirigente controla los otros poderes. En este país en que la Iglesia y el Estado 
están unidos, la Iglesia es un instrumento de la clase dirigente. Cuando, por otra parte, la Iglesia posee un vasto poder económico y un poder en el dominio de la educación, participa en el poder de la minoría dirigente (Torres, 1968, p. 189).

¿Qué es la revolución para Camilo?

La presión que se ejerce a fin de obtener un cambio revolucionario es aquella que tiende a cambiar las estructuras. Se trata sobre todo de un cambio en la estructura de la propiedad, del ingreso, de las inversiones, del consumo, de la educación y de la organización política y administrativa. Pretende, igualmente, un cambio en las relaciones internacionales de naturaleza política, económica y cultural (Torres, 1968, p. 196).

Así, Camilo llega a las siguientes conclusiones:

- Los cambios de estructura en los países subdesarrollados no podrán producirse sin una presión de la clase popular.

- Las oportunidades de revolución pacífica están ligadas a la previsión de la clase dirigente, pues su voluntad de cambios es dificil de obtener.

- La revolución violenta es una alternativa que se presenta como bastante probable, vista la dificultad de la clase dirigente para prever (Torres, 1968, p. 199).

Ante la realidad social y las exigencias de su fe:

el cristiano debe adoptar una actitud que no traicione la práctica de la caridad (...) Como Cristo, debe encarnarse en la humanidad, en su historia y en su cultura. Por eso debe buscar la aplicación de su vida sobrenatural en las estructuras económicas y sociales, sobre las que debe actuar (Torres, 1968, p. 201).

¿Y los medios? Se presenta un problema moral:

Cuando hay fines malos como consecuencia del fin esencial, o cuando se utilizan prácticamente medios malos. En esta hipótesis, el rechazo o la abstención no son siempre necesarios, mientras no se haya probado el género de mal que se evita y cuál es la relación de causalidad entre los fines malos y los buenos - causalidad eficiente, total, esencial, etc. En la realidad histórica de los países subdesarrollados, estas circunstancias son difíciles de comprobar. La revolución es una empresa tan compleja que sería artificial situarla en un sistema de causalidades y finalidades tan uniformemente malo. Los medios pueden 
ser diferentes y, en el curso de la acción, es fácil realizar modificaciones (Torres, 1968, p. 206).

Al fin, en 22 de mayo de 1965, Camilo lanza su famosa plataforma:

Motivos:

1. Las decisiones necesarias para que la politica colombiana se oriente en beneficio de la mayoría y no de las minorias, tendrian que partir de los que detentan el poder.

2. Los que poseen actualmente el poder real constituyen una minoría de carácter económico que produce todas las decisiones fundamentales de la politica nacional.

3. Esta minoría nunca producirá decisiones que afecten sus propios intereses ni los intereses extranjeros a los cuales está ligada.

4. Las decisiones requeridas para un desarrollo socioeconómico del país en función de las mayorías y por la vía de la independencia nacional afectan necesariamente los intereses de la minoría económica.

5. Estas circunstancias hacen indispensable un cambio de la estructura del poder político para que las mayorias produzcan las decisiones.

6. Actualmente las mayorias rechazan os partidos politicos y rechazan el sistema vigente, pero no tienen un aparato político apto para tomar el poder.

7. El aparato político que debe organizarse debe aprovechar al máximo el apoyo delas masas, debe tener una planeación técnica y debe constituirse alrededor de los principios de acción más que alrededor de un líder para que se evite e peligro de las camarillas, de la demagogia y del personalismo (Torres, 1968, pp. 227228).

A final de la plataforma, se encuentra el siguiente anexo:

El Padre Camilo Torres ha declarado que es revolucionario en tanto que colombiano, sociólogo, cristiano y sacerdote:

- Como colombiano porque no puede permanecer ajeno a las luchas de su Pueblo.

- Como sociólogo, porque, gracias al conocimiento científico que tiene de la realidad, ha llegado al convencimiento de que no puede haber soluciones técnicas y eficaces sin una revolución. 
- Como cristiano, porque la esencia del cristianismo es el amor al prójimo, y el bien de la mayoría no puede obtenerse más que por la revolución.

- Como sacerdote, porque el don de sí mismo al prójimo que exige la revolución es una condición de caridad fraterna, indispensable para la realización digna de su misión (Torres, 1968, p. 231).

En su declaración sobre la carta escrita al Cardenal Concha, del 25 de junio de 1965, dice:

Cuando existen circunstancias que impiden a los hombres entregarse a Cristo, el sacerdote tiene como función propia combatir esas circunstancias, aun a costa de su posibilidad de celebrar el rito eucarístico que no se entiende sin la entrega de los cristianos.

En la estructura actual de la Iglesia se me ha hecho imposible continuar el ejercicio de mi sacerdocio en los aspectos del culto externo. Sin embargo, e sacerdocio cristiano no consiste únicamente en la celebración de los ritos externos. La Misa, que es el objetivo final de la acción sacerdotal, es una acción fundamentalmente comunitaria. Pero la comunidad cristiana no puede ofrecer en forma auténtica el sacrificio si antes no ha realizado en forma efectiva el precepto del amor al prójimo.

Yo opté por el cristianismo por considerar que en él encontraba la forma más pura de servir a mi prójimo. Fui elegido por Cristo para ser sacerdote eternamente, motivado por el deseo de entregarme de tiempo completo al amor de mis semejantes. Como sociólogo he querido que ese amor se vuelva eficaz, mediante la técnica y la ciencia; al analizar la sociedad colombiana me he dado cuenta de la necesidad de una revolución para poder dar de comer al hambriento, de beber al sediento, vestir al desnudo y realizar el bienestar de las mayorías de nuestro pueblo. Estimo que la lucha revolucionaria es una lucha cristiana y sacerdotal. Solamente por ella, en las circunstancias concretas de nuestra patria podemos realizar el amor que los hombres deben tener a su prójimo (Torres, 1968, pp. 248-249).

¿E justificable la intervención activa y revolucionaria de un sacerdote en la politica, más aún, en la revolución incluso violenta? Veamos la respuesta de Camilo en un trabajo sin fecha, cuyo título es La Iglesia de América Latina en la encrucijada:

Ver a un sacerdote mezclado en las luchas políticas y abandonando el ejercicio exterior de su sacerdocio es algo que repugna nuestra mentalidad tradicional. A pesar de todos, pensamos verdaderamente que pueden existir 
razones de amor para con el prójimo y de testimonio, auténticamente sacerdotales, $y$ que fuerzan a este compromiso, si se quiere estar en paz con la propia conciencia y, por lo tanto, con Dios.

Cuando los cristianos vivan fundamentalmente para el amor y para permitir a los demás amar, cuando la fe sea una fe inspirada en la vida y, más concretamente, en la vida de Dios, de Jesús y de la Iglesia, cuando el rito externo coincida con la verdadera expresión del amor en la comunidad humana, entonces podremos decir que la Iglesia es fuerte, no por el poder económico o político, sino por la caridad.

Si el compromiso temporal de un sacerdote en las luchas politicas puede contribuir a ello, su sacrificio es justificable. (Torres, 1968, pp. 276-277).

Finalmente, copiemos su mensaje a los cristianos, del 26 de agosto de 1965, ya con ciertos tonos demagógicos, y que resume mejor que nada su opción revolucionaria:

Las convulsiones causadas por los acontecimientos politicos, religiosos y sociales de estos últimos tiempos han sumido probablemente a los cristianos de Colombia en la más grande confusión. Es preciso que en este momento decisivo de nuestra historia, los cristianos nos mantengamos firmes en las bases esenciales de nuestra religión. La principal, en el catolicismo, es el amor al prójimo. "Quien ama a su prójimo ha cumplido la ley" (Ro $13,8)$.

Para que este amor sea verdadero, hay que buscar la eficacia. Si la beneficencia, la limosna, las pocas escuelas gratuitas, el pequeño número de planes de urbanismo, todo eso que se ha llamado "la caridad" no basta para dar de comer a todos los hambrientos, ni vestir a la mayoría de los que están desnudos, ni para enseñar a los que no saben, debemos buscar medios eficaces para el bienestar de las masas.

Las minorias privilegiadas que detentan el poder no van a buscar esos medios, pues por lo general los medios eficaces obligan a las minorias a sacrificar sus privilegios... Por lo tanto, es preciso quitar el poder a las minorias privilegiadas para dárselo a las mayorias pobres. Que esto se realice rápidamente es lo esencial de una revolución. La revolución puede ser pacífica si las minorias no oponen una resistencia violenta.

Así, la revolución es la manera de obtener un gobierno que dé de comer al hambriento, que vista al desnudo, que enseñe al que no sabe, que cumpla con su deber caritativo, 
con su deber de amor al prójimo, no sólo de una manera ocasional y transitoria, no sólo para algunos, sino para la mayoría de nuestros semejantes. Por eso la revolución no es algo solamente permitido, sino obligatorio para los cristianos, quienes ven en ella la única manera eficaz de realizar el amor a todos. Es cierto que "no hay autoridad que no venga de Dios" (Rom 1, 1). Pero Santo Tomás explica que la atribución de la autoridad procede concretamente del pueblo.

Cuando se instaura una autoridad contra el pueblo, esta autoridad no es legítima y se llama tiranía. Los cristianos podemos y debemos luchar contra la tiranía. El gobierno actual es tiránico, pues se apoya, no en el pueblo, sino en un $20 \%$ de los electores, y porque sus decisiones provienen de las minorias privilegiadas.

Las faltas temporales de la Iglesia no deben escandalizarnos. La Iglesia es humana. Lo importante es creer igualmente que es divina y que si los cristianos cumplimos nuestro deber reforzamos la Iglesia.

Yo he dejado los deberes y los privilegios del clero, pero no he dejado de ser sacerdote. Creo que me he entregado a la revolución por amor al prójimo. He dejado de decir la misa para realizar ese amor al prójimo en el terreno temporal, económico y social. Cuando mi prójimo no tenga nada contra mí, cuando la revolución se haya realizado, volveré a ofrecer la Misa, si Dios me lo permito. Creo seguir así el mandato de Cristo: "Si vas, pues, a presentar tu ofrenda ante el altar y alli te acuerdas de que tu hermano tiene algo contra ti, deja alli tu ofrenda, ante el altar, ve primero a reconciliarte con tu hermano y entonces vuelve a presentar tu ofrenda" (Mt 5, 23-24). Después de la revolución, los cristianos seremos conscientes de haber establecido un sistema fundado sobre el amor al prójimo (Torres, 1968).

Comentario: Como en el caso de Martin L. King (y de una forma más acusada, si cabe) es muy difícil juzgar la postura de Camilo Torres, ya que su doctrina va indisolublemente ligada a su vida y a la situación concreta que le tocó vivir. Valgan dos rasgos que nos parecen fundamentales: 1) Camilo cree poder realizar una revolución violenta, no sólo con amor al contrario, sino incluso por amor. 2) Aun suponiendo que no eligiera los medios más convenientes desde el punto de vista de la eficacia, la vida y pensamiento de Camilo quedan indudablemente como un auténtico testimonio profético. En esto, suscribimos el juicio de F. Houtart (1968, p. 151):

Se puede pensar lo que se quiera sobre su eficacia politica; se puede estar o no de acuerdo con su plataforma política; se pueden hacer objeciones sobre la forma de hacer 
evolucionar su movimiento, pero jamás se podrá negar el carácter profético del papel sacerdotal de Camilo Torres.

\section{Conclusiones}

A manera de resumen final, podemos sacar de esta rápida revisión de teorias sobre una posible teología y praxis cristiana de la revolución algunas conclusiones que parecen imponerse como evidencia común.

\section{El cristiano debe comprometerse con el mundo histórico}

Es una exigencia fundamental de su misma fe. Dios "abandona" el mundo en manos de los hombres, para que estos lo sigan creando. Desde el punto de vista cristiano, para que vayan dando forma al Reino de Dios, cuya culminación supondrá el fin de los tiempos. Por lo tanto, la fe tiene exigencias concretas y determinadas, según las circunstancias sociales y humanas en que toque vivir a cada cristiano. Por otra parte, la utopía escatológica y la radicalidad absoluta y única de Dios impiden cualquier idolatría de un determinado orden mundano ya establecido. En este sentido, la actitud del cristiano ha de ser necesariamente profética y revolucionaria.

La conciencia de que se trabaja por una utopía (una escatología) no permite en ninguna manera la evasión espiritualista del cristiano. Tampoco el saber que trabaja "a largo plazo" le exime de la necesidad de una opción "a corto plazo". Porque este tiempo "corto" es históricamente capital (Cousso, 1966). Es el tiempo político, el de las guerras y revoluciones, donde se juega la supervivencia concreta de un estado. El cristiano no puede ignorar este tiempo corto, pues está en el origen del tiempo largo.

\section{El mundo actual exige una revolución urgente}

La injusticia institucionalizada, el desorden legalizado, en el que sólo una minoría infima pueden ser verdaderamente hombres, mientras la gran masa de seres humanos se debate en la miseria más infamante, no admiten dudas ni demoras. Existen en nuestra sociedad una violencia permanente, amparada por una legislación que nada justifica. La revolución es, pues, una exigencia inaplazable, y tal vez la primera cosa que exija esta revolución sea la toma de conciencia por parte de todos (pobres y ricos) de su necesidad absoluta. 


\section{El espiritu cristiano en la revolución}

Tanto por su realidad de hombre como por exigencias de su fe, el cristiano está obligado a tomar parte activa en esta revolución. En sus manos está el desempeñar un papel personal y dar a la revolución el espíritu del que tal vez otros hombres carecen (o que, por lo menos, a él se le presenta como más evidente, puesto que tiene el módulo de la Palabra de Dios revelada). En este sentido, si del Antiguo Testamento el cristiano puede sacer el espíritu profético, por el que se ha de oponer a todo tipo de idolatría (e idolatría es la absolutización de cualquier sistema establecido), el Nuevo Testamento le enseña la fuerza revolucionaria del verdadero amor. Tal vez la síntesis de este espíritu se encuentra en la violencia pacífica: la llamada no-violencia.

\section{El cristiano debe buscar una acción revolucionaria eficaz}

Admitida la necesidad de la revolución, el problema se cifra en la elección de los medios más adecuados para conseguir el fin. No se puede condenar a priori la violencia (entendida como presión o fuerza incluso física), ya que la violencia se encuentra ya en la sociedad establecida. Ni tampoco hay necesidad de acudir al concepto tradicional de legitima defensa como justificación, que supondria un enfrentamiento del amor propio al amor del prójimo y, por lo tanto, una concesión a cierto egoísmo. La violencia puede estar justificada desde el momento en que hay un estado de injusticia y, por consiguiente, el valor justicia se encuentra en colisión con el valor amor al prójimo. Es verdad que la violencia debe quedar siempre como una opción última y provisional. Pero es precisamente la eficacia la que, en las circunstancias actuales nos hace optar por la no-violencia, ya que la fuerza del poder establecido tiene capacidad más que suficiente para aplastar cualquier brote revolucionario directamente violento. En este sentido, usar la violencia armada puede ser la disculpa que el poder establecido espera para proceder a la represión más salvaje (y estas circunstancias las estamos viviendo ya por doquier).

\section{El cristiano no puede absolutizar la revolución}

La revolución no es un fin en sí misma, sino un medio para conseguir una sociedad más justa, una sociedad más próxima al Reino de Dios escatológico. Por ello, el cristiano no puede absolutizar el valor de la revolución. Si su postura ante el orden establecido ha de ser crítica, crítica ha de ser también su postura ante su propia opción revolucionaria. Olvidar esta realidad, sería incurrir en una nueva idolatría. Esto ha de tenerse muy principalmente en cuenta si en un momento determinado se opta por el empleo de la violencia armada. 


\section{La Iglesia debe comprometerse como Institución}

No sólo al cristiano como tal compete el adoptar una postura revolucionaria. La misma Iglesia como Institución debe tomar partido en la lucha histórica contra todo tipo de idolatria. Y esto por dos razones: 1) Por su función esencialmente escatológica -de donde su testimonio profético y su oposición a todo tipo de absolutización. 2) Por justicia histórica. La Iglesia debe necesariamente reparar el inmenso pecado de omisión que ha cometido a lo largo de la historia con los pobres, olvidándose de ellos, dándoles de lado, predicándoles una fe conformista e inhumana, aliándose con el poder político y económico. Esta reparación es de una gran urgencia, y cualquier tipo de disculpa o reticencia no haría sino agravarlo todavía más.

\section{Pasar a la acción}

Todo lo dicho hasta acá no servirá de nada si se queda en palabras. Porque la "teología de la revolución" sólo tiene valor en función directa de una acción. En este sentido, el testimonio de Camilo Torres, de Martin L. King o de Monseñor Helder Câmara debe servirnos de ejemplo. La Iglesia ha hablado ya demasiado. El mundo -aunque aparentemente pregunte de una manera teórica- sólo espera de nosotros una respuesta, la única que necesita: que la Iglesia actúe, que se ponga en movimiento. Que ame realmente.

\section{¿Y yo?}

Esta es la pregunta que necesariamente debemos formularnos cada uno de nosotros. La peor de las conclusiones sería una aprobación teórica, en el plano intelectual, pero una dimisión práctica a la hora de ponerse en movimiento. No podemos eludir nuestra responsabilidad personal. Nuestra situación concreta no es ninguna excepción. Y no lo es, porque también cada uno de nosotros necesita convertirse personalmente (revolución personal, interior), y transformar el ambiente que nos rodea, la estructura social en que vivimos (revolución social). Hay que ponerse en marcha inmediatamente, hoy mismo, en este momento...

\section{Referencias}

Bigo, P. (1968). Enseñanza de la Iglesia sobre la violencia. Mensaje, 174, 574-578.

Blaise, M. (1966). Violence libératrice et conscience chrétienne. Frères du Monde, 40-41, 89-98.

Blanquart, P. (1968). Foi chrétienne et révolution. Em A la recherche d'une théologie de la violence 9 (pp. 137-155). Paris: Ed. Du Cerf. 
Câmara, H. (1968a). Le tiers monde trahi. Paris: Desclée de Brouwer.(1968).

Câmara, H. (1968b). Acción no violenta en América Latina. Mensaje N. $174,579-583$.

Câmara, H. (1968c). Seule la justice évitera la révolte du Tiers-Monde. Labor, 41, 275-277.

Câmara, H. (1968d). La violence: Option unique? ICI, 15, 04-07.

Certeau, M. de (1968). La révolution fondatrice, ou le risque d'exister. Etudes, 80-101.

Cousso, R. (1966). Le Chrétien et les combats des hommes. Frères du monde, 40-41, 145-156.

Dia, D. (1962). Education dans les pays latino-américains. Fribourg: Feres.

Domergue, R. (1966). Réflexions sur la violence. Frères du monde, 40-41, 24-64.

Ellacuría, I. (1969). Violencia y cruz. En J. M Setién (Org.), ¿Qué aporta el cristianismo al hombre de hoy? IV Semana de Teologia (pp. 259-308. Bilbao: Universidad de Deusto.

González Ruiz, J. M. Carácter social y público del mensaje cristiano. Concilium, 36, 75-84.

Houtart, F. (1968). La carta del P. Arrupe. En Varios Autores, La carta del P. Arrupe: Requiem por el constantinismo. Barcelona: Nova Terra.

King, M. L. (1968a). La force d'aimer. Paris: Castermann.

King, M. L. (1968b). Où allons-nous? Paris: Payot.

King, M. L. (1968c). La seule revolution. Paris: Casterman.

Lasserre, J. (1965). Les chrétiens et la violence. Paris: Ed. De la Réconciliation.

Lasserre, J. (1968). La révolution de la croix. Cahiers de la Réconciliation, 8-9, 29-34.

Le Guillou, C. (1968). Evangile et révolution au coeur de notre crise spiritualle. Paris: Ed. Du Centrurion.

Lochman, J. M. (1968). Ecumenical theology of revolution. Scot. Journal of Theology, 21, 170-186.

Millar, O. (1968). Révolution et non-violence. Conferencia presentada en el Congrès du Mouvement International de la Réconciliation, Bièvres, Francia.

Pablo VI (1967). Populorum Progressio.

Rondet, M. (1968). Contestation et discernement. Christus, 60, 475-482. 
Schüller, B. (1966). Gesetz und Freiheit. Düsseldorf: Patmos.

Serrand, A. Z. (1968). Evangile et violence. Signes du Temps, 26-31.

Shaull, R. (1966). Evolutionary change in theological perspective. En J. C. Bennett (Comp.), Christian ethics in a changing world (pp. 23-43). New York: Association SCM Press.

Shaull, R. (1968a). Conferencia dictada en CICOP. CIDOC, 68/58.

Snoek, C. J. (1966). Tercer mundo: Revolución y cristianismo. Concilium, $15,34-53$.

Swomley Jr., J. M. (1967). Justice, révolution et violence. Cahiers de la Réconciliation, 6, 5-16.

Toaldo, E. (1968). La situazione prerivoluzionaria del Terzo Mondo. Le Missioni Cattoliche, 6-7, 344-364.

Torres, C. (1968). Ecrits et paroles. Paris: Ed. du Seuil. 